\title{
A Review of Urban Green and Blue Infrastructure from the Perspective of Food-Energy-Water Nexus
}

\author{
Aamir Mehmood Shah ${ }^{1}{ }^{(\mathbb{D}}$, Gengyuan Liu ${ }^{1,2, * \mathbb{D}}$, Fanxin Meng ${ }^{1}$, Qing Yang ${ }^{3}$, Jingyan Xue ${ }^{1}$, Stefano Dumontet ${ }^{4}$, \\ Renato Passaro $^{5}$ iD and Marco Casazza ${ }^{4,6}$ iD
}

1 State Key Joint Laboratory of Environment Simulation and Pollution Control, School of Environment, Beijing Normal University, Beijing 100875, China; aamirmehmood55@hotmail.com (A.M.S.); fanxin.meng@bnu.edu.cn (F.M.); 201831180024@mail.bnu.edu.cn (J.X.)

2 Beijing Engineering Research Center for Watershed Environmental Restoration \& Integrated Ecological Regulation, Beijing 100875, China

3 Key Laboratory for City Cluster Environmental Safety and Green Development of the Ministry of Education, Institute of Environmental and Ecological Engineering, Guangdong University of Technology, Guangzhou 510006, China; yangqing14@mails.ucas.edu.cn

4 Centro Direzionale, Department of Sciences and Technologies, University of Napoli 'Parthenope', Isola C4, 80143 Napoli, Italy; stefano.dumontet@uniparthenope.it (S.D.); marco.casazza001@studenti.uniparthenope.it (M.C.)

5 Centro Direzionale, Department of Engineerinng, University of Napoli ‘Parthenope', Isola C4, 80143 Napoli, Italy; renato.passaro@uniparthenope.it

check for updates

Citation: Shah, A.M.; Liu, G.; Meng, F.; Yang, Q.; Xue, J.; Dumontet, S.; Passaro, R.; Casazza, M. A Review of Urban Green and Blue Infrastructure from the Perspective of Food-Energy-Water Nexus. Energies 2021, 14, 4583. https://doi.org/ $10.3390 /$ en14154583

\section{Academic Editors: Rajendra}

Singh Adhikari, Sergio Ulgiati and Ricardo J. Bessa

Received: 15 April 2021

Accepted: 17 July 2021

Published: 29 July 2021

Publisher's Note: MDPI stays neutral with regard to jurisdictional claims in published maps and institutional affiliations.

Copyright: (c) 2021 by the authors. Licensee MDPI, Basel, Switzerland. This article is an open access article distributed under the terms and conditions of the Creative Commons Attribution (CC BY) license (https:// creativecommons.org/licenses/by/ $4.0 /)$.
6 Interdepartmental Research Centre on Urban and Event Studies (OMERO), University of Torino, Lungo Dora Siena 100 A, 10153 Torino, Italy

* Correspondence: liugengyuan@bnu.edu.cn

Abstract: Small scale urban green-blue infrastructure (indicated as GBI hereafter) comprises huge underexploited areas for urban development and planning. This review article aims to highlight the relevance and knowledge gaps regarding GBI from the perspective of the food-energy-water (FEW) nexus, these being key resources for the survival of human communities. In particular, this review was focused on publications on urban ecosystem services (positive effects) and dis-services (negative effects) associated with different GBI typologies. The review proved that GBI can contribute environmentally, socially, and economically to FEW security and urban sustainability. Yet, such positive effects must be considered against ecosystem dis-services tradeoffs, including urban food production, commonly connected with heavy water and energy consumption, specifically under dry climate conditions, and sometimes related to an excessive use of manure, pesticides, or fertilizers. These conditions could pose either a risk to water quality and local insect survival or serve enhanced mosquito breeding because of irrigation. Up to now, the review evidenced that few nexus modeling techniques have been discussed in terms of their benefits, drawbacks, and applications. Guidance is provided on the choice of an adequate modeling approach. Water, energy, and food are intrinsically associated physically. However, depending on their management, their tradeoffs are often increased. There is a need to minimize these tradeoffs and to build up synergies between food, energy, and water using a holistic approach. This is why the FEW nexus approach offers good insights to address the relation between three important individual resource components of sustainability.

Keywords: green-blue infrastructure; food-energy-water nexus; tradeoff; small scale urban system

\section{Introduction}

Urban population growth, which is expected to reach $68 \%$ of the global population by 2050 [1], is impacting on the demand and use of available resources. Land areas covered by cities are expected to increase up to 1.3 million $\mathrm{km}^{2}$ between 2015 to 2050 [2]. Such trends will influence the demand for food, energy, and water [3]. Biodiversity loss will also increase, together with the fragmentation of habitats and their associated ecosystem 
functionality, generating further adverse impacts [4]. This is why a transition towards a sustainable lifestyle is necessary and should be accelerated to decrease the consumption of resources and to minimize the existing environmental impacts. Such dynamics are also influenced by urban infrastructures. However, their role is less considered, with the attention often focused on resource flows as separate from their context.

Concerning the flow of key resources for human survival, food, energy, and water can be interrelated with green and blue infrastructure (GBI). GBI is defined as a network of landscape components, which include green areas and water bodies [5]. Such an infrastructure, available within an urban space, provides diverse environmental, economic, and social benefits to people and other living organisms [6]. This green-blue system can perform various functions, having the potential to produce multiple services, such as food, water purification, temperature regulation, and others, which are crucial for urban adaptability [7]. Several developed countries implemented their GBI to minimize the urban heat effects (Germany, Australia), carbon storage (South Africa), surface runoff (Brazil, Netherland, USA), and food production (Singapore) [8].

From a human perspective, in parallel to ecosystem services (ES), GBI can also produce some dis-services [9]. For example, while the cultivation of vegetables generates food to support humans, it might require a huge amount of water supply. For instance, $200 \mathrm{~L}$ of water are required to produce $1 \mathrm{~kg}$ of vegetables [10]. Trees in the urban environment provide regulating support, by cooling or shading effects in Summer and protection against the chilled wind in Winter [11]. Nonetheless, trees might need water in abundance [12]. On the other hand, the cultivation of fruit trees, with known edibles such as apples (Malus spp.), cherries (Prunus spp.), and pears (Pyrus spp.), is prohibited in urban streets due to the falling of their fruits on footpath and stroller injuries [13]. Green roofs (GRs) are capable of minimizing the energy consumption of buildings and reducing the fluctuation of indoor temperatures in cold as well as warm weather conditions [14]. Sometimes, the conservation of energy utilization can be induced, due to unexpected natural factors (e.g., the rainfall will reduce the requirements of extra water) [15]. Moreover, GRs reduce stormwater runoffs [16], which may include heavy metals such as $\mathrm{Fe}, \mathrm{Zn}, \mathrm{Cu}$, and $\mathrm{Al}$ [17]. According to the authors' observations, large amounts of metals can be upheld $(92 \%$ of $\mathrm{Cd}$, $99 \%$ of $\mathrm{Pb}, 97 \%$ of $\mathrm{Cu}$, and $96 \%$ of $\mathrm{Zn}$ ), especially in summer. However, such heavy metals might contaminate the vegetables [18].

Food, water, and energy are key inter-linked resources for the survival of individuals and human communities [19]. Such a mutual relation among different resources and their dynamics is synthesized through the nexus concept and framework [20,21]. For instance, energy used for food production, landfill gas, and waste from food consumption and production can be used for energy generation [22,23]. Food production and consumption also use water and generate wastewater [24,25]. Energy is needed for water treatment processes, while energy production requires water, generating wastewater [26,27].

The concept of the food-energy-water (FEW) nexus was proposed at the Bonn 2011 Nexus Conference, it being regarded as important to enhance food, energy, and water security [28]. The nexus concept has become extensively discussed in the scholarly research literature. In fact, a better understanding of FEW dynamic linkages will help to resolve the challenges of FEW insecurity, supporting the reduction of several impacts of anthropogenic activities. Such an understanding will also help to identify and evaluate the synergies and trade-offs among these resources [29-31]. The nexus holistic approach supports an integrated management across different scales and economic sectors, generating a higher resource efficacy. This is why it has become relevant for urban planning and management [32,33].

However, FEW nexus should be further integrated with ecosystems [29]. In fact, this integration would support the achievement of sustainable development goals [34]. GBI can act as a unifying spatial and functional (referred to provided ecosystem services) framework, as well as a system within which flows of food, energy, and water exist and can be quantified. Figure 1 illustrates the nexus structure. The food production practices drive 
energy use intensities and water extraction rates. At the same time, food and water are also essential for energy, whereas electricity and food production processes are essential for water safety. Water is demanded to produce electricity, e.g., hydropower, and the harvesting of biomass which is used for biofuel production. Birol and Das [35] reported that around $15 \%$ of global water extraction is consumed for the production of energy. Energy is essential for the transport, pumping, and treatment of portable and non-portable water, i.e., wastewater, for human utilization and vegetation. On the contrary, approximately $8 \%$ of energy is used for water purposes worldly [36]. Regarding power generation integration in the water cycle, some of the GBI, e.g., constructed wetlands, can provide opportunities to mitigate energy consumption, for instance, it generates humus as well as nutrient-rich effluent water that can be utilized directly to irrigate energy crops and for short rotation vegetation through fertigation process $[37,38]$. Moreover, the treated water can be used for flush toilets, street vegetation, and washing the roads, and also to reduce the extra energy burden that is required for wastewater treatment. This is why a "GBI-FEW" nexus can be considered in the study of urban metabolism, with the purpose of a better management of resources, supporting the transition to more sustainable energy systems.

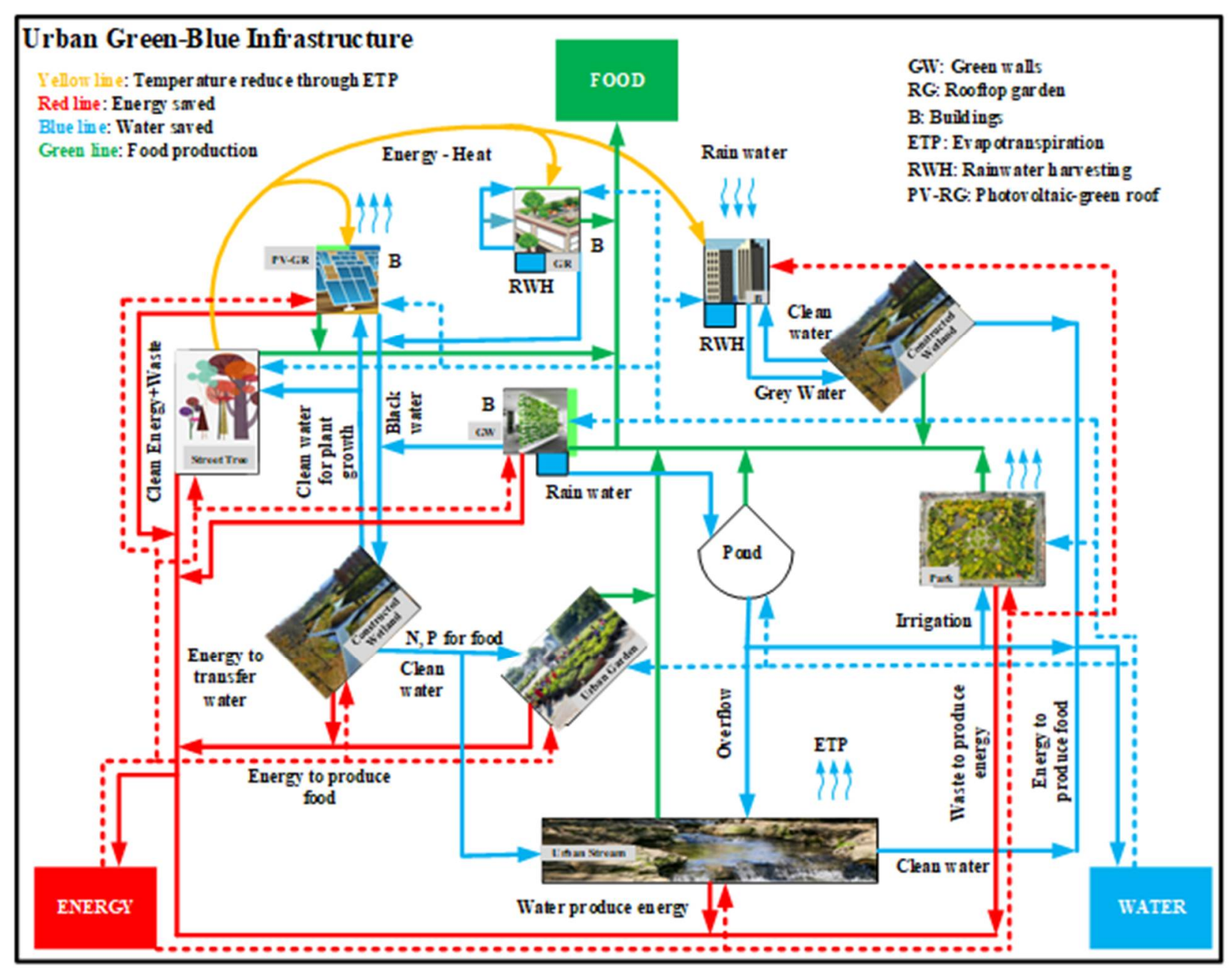

Figure 1. The sustainable "GBI-FEWN" management framework in an urban settlement.

In this review article, we focus on the following issues: (i) The ecological benefits and drawbacks of GBI in urban centers from the perspective of FEW nexus; (ii) The changes in trade-offs of FEW nexus in urban GBI with spatial planning and governance in cities; (iii) The design of a GBI energy framework concerning FEW nexus to promote better city interventions and decision-making processes. 


\section{Materials and Methods}

A general search was conducted using the electronic journal database "Science Direct" for recent systematic scientific literature, to identify and examine the small-scale green and blue infrastructure which influences the food, energy, water nexus in the urban system.

During the search, the following English language keywords were selected separately: ("Green roofs" OR "food" OR "water" OR "energy"); (“Urban garden” OR "food" OR "water" OR "energy"); ("Constructed wetland" OR [ ... ] "Bio-swales") (Further details available in supplementary material). The search was limited to specific document types (review articles, research articles, conference proceedings, and book chapters etc.). We considered a timeframe between 2011 and 2020, since the nexus became more important in international academia globally after the Bonn 2011 conference [28]. With the current search criteria, a total of 873 articles were retrieved.

These articles (873) were further screened based on the following criteria. Firstly, the study used the GBI and FEW nexus concepts. Secondly, the study carried out its nexus studies in either a specific city or urban cities within a country. Finally, the research examines and quantifies multiple environmental benefits and negative externalities of GBI that influence the nexus. Publications that did not meet the following criteria were excluded from this paper. After the last screening process, the variables such as the title of the paper, journal type, nexus type/structure, objectives of the study, the scale of the study, data source, model use, the outcomes of the study, and other variables were assembled for further analysis. Moreover, by using the outcomes from our finalized scientific literature, we apply bibliometric techniques to identify positive (ES) and negative (dis-services) effects associated with the GBI in Figure 2. Bibliometric technique helps to reveal the structures, characteristics and patterns of a specific topic, as well as research hotspots and future trends [39]. Further, Science Direct electronic database was employed to extract relevant data of selected publications such as journal title, published year, citations, address, authors, keywords, and other information. The search information system (RIS) files then treated by VOSviewer software to generate the cluster and networks of different terms used in literature.

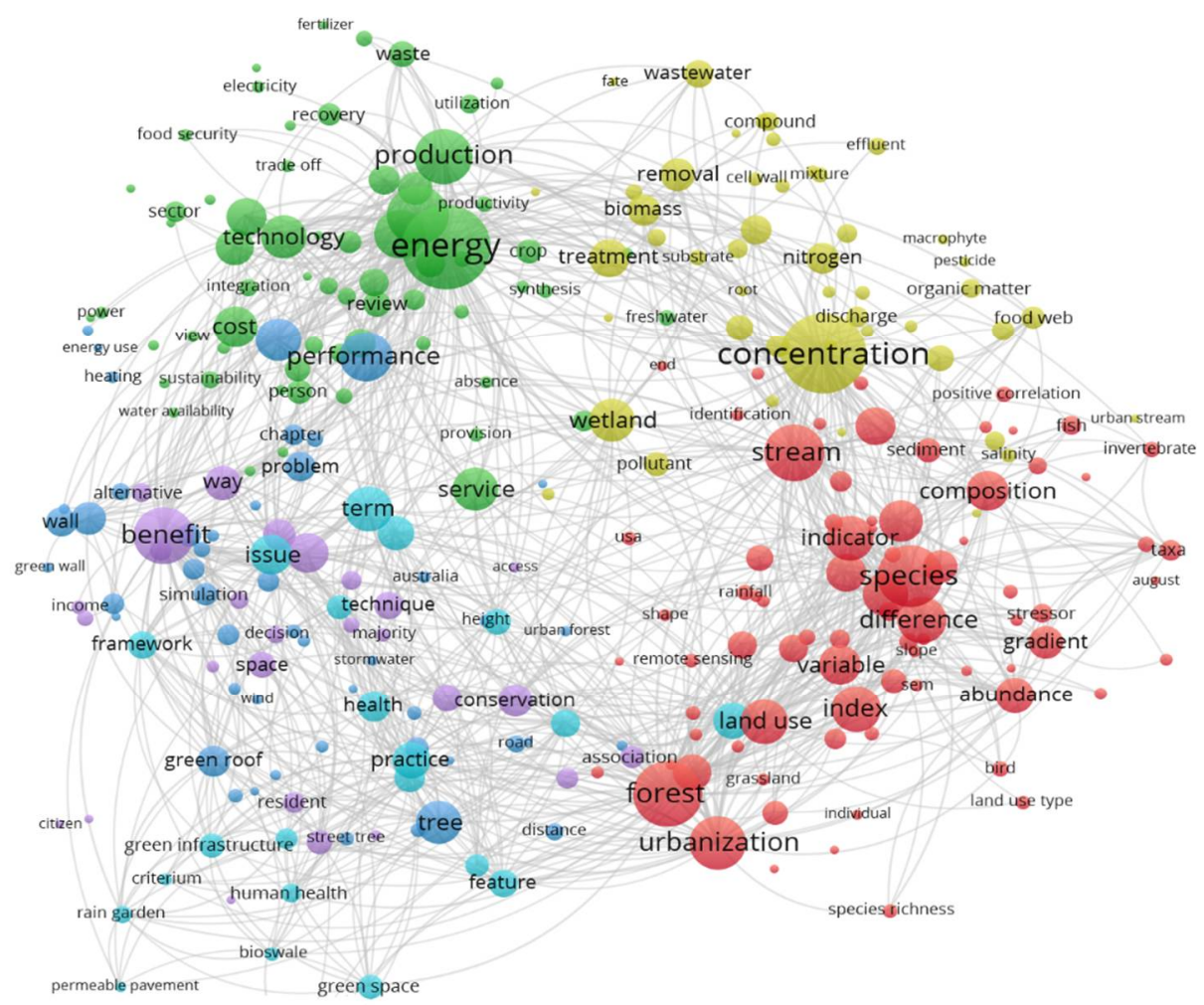

Figure 2. GBI-FEW nexus keywords correlation graph through bibliometric analysis. 


\section{Effects of Green and Blue Infrastructure on FEW Nexus}

The idea of Urban green structure emerged in the 1870s with the concept of garden allotments and urban agriculture [40]. Later, the green infrastructure term originated in the 1980s mid, suggestion for well management practices to achieve more rainwater quantity management goals for runoff volume reduction [41]. Compared to its precursors, GBI or BGI are relatively new terms, first appearing in the 2000s [42], and are used for explaining the planning efforts in the city of Brazil, Sao Paulo, to generate the network of GBI in the reaction of flood risks [43]. In the beginning, managers and planners only thought about the specific requirements of selected areas, such as food or water provision, considering one service per time. Later, city authorities and experts considered that GBI produces more than one service (also called two nodes or three-node nexus). For example, Baro et al. [44] studied that street trees mitigate storm-water runoff and regulate the urban temperature. Moreover, few researchers highlighted that GBI also not only reduces temperature and saves water but also produces food. For example, Baek and Han [45] reported that concave GR provides vegetables, saves energy, and stores water.

In terms of nodes number, nexus can be divided into two categories: (1) Two-node nexus research such as water-land [46], food-energy [47], and energy-water [48]; (2) Three-node nexus research such as water-energy-climate [49], energy-food-water [50], water-soil-waste [51], environment-water-climate [52], and land use-climate changeenergy [53].

\subsection{Two Node Nexus}

\subsubsection{Water-Energy Nexus}

The usage of water, supply and disposal requires energy [54]. For example, about $19 \%$ of the electricity of California's requires a huge amount of water supply [55] and 2-3\% of energy usage of Ontario's goes in the direction of water treatment for the supply to urban population and relevant municipal industries [56]. Conversely, water is required for power production and the exploitation of energy. In the USA, an estimated $41 \%$ of freshwater was withdrawn for power generation in 2005 [57].

In the planning and construction of urban GBI, a balance between energy and water should be maintained [58]. This fact was proved, for example, estimating the total runoff mitigation and regulation of urban temperature provided by 200,000 trees alongside Spain streets using the i-Tree Eco tool [44]. This study revealed that trees in Barcelona, during 2015 , were able to regulate an amount of water equivalent to $52,668 \mathrm{~m}^{3}$ for runoff and $840,408 \mathrm{~m}^{3}$ of surface waters. Another study evaluated the irrigation requirements and energy performance of green roofs in drought Mediterranean climates [59]. They quantified that plant species water requirements ranged from 2.6 to $9.0 \mathrm{~L} / \mathrm{m}^{2}$ per day. The most efficient plant variety in terms of water usage was Aptenia cordifolia, providing higher cooling benefits (per unit water) for irrigation. The cooling efficiency of root variants was low and the drop in functional heat load of model buildings ascribed to the green roof system was lower than $5 \%$ of latent heat of water lost to evaporation. In these environmental conditions, it is difficult to see the real benefits of green roofs for building energy saving, even considering their additional advantages.

In traditional cities, rainwater and waste are often mismanaged. Urban waterlogging results from a large amount of rainwater runoff and from collected rainwater. The removal and treatment of waste transported by rainwater consumes a great amount of energy. Gray infrastructure is employed to treat the rainwater, through the urban sewer system [60]. However, wastewater treatment requires a lot of energy, whereas natural GBI could be used with the same purpose. Drainage and water cycling often require to be supported by energy. For energy conservation in green-blue urban construction, an integrative approach would be desirable. While constructing the sponge cities, the usage of gray infrastructure should be reduced. With this respect, more attention should be given to a comprehensive green infrastructure [60]. The construction of green infrastructure systems on urban areas can allow rainwater to penetrate underground soils via filtration and minimize the surface 
rainwater runoffs to cut flood catastrophes as well as water storage. In addition, these green infrastructures can make use of duplicate vegetation via self-purification phenomena. Their repeated reuse diminishes the energy consumption from tap water [61].

\subsubsection{Food-Water Nexus}

Various solutions have been applied to urban stormwater management, such as rain gardens (bio-filtration or bio-retention systems) to protect water pathways via treating, retaining, and utilization of stormwater sources [62]. Green roofs (GR), along with rain gardens, have the potential to grow vegetables as well as retain stormwater runoff [63]. During drought conditions, stormwater may increase the safety of the water supply, when constraints on potable water usage may be executed. These limitations were employed in Australia between 2002 to 2012. However, restrictions on outside watering effectively limited the production of urban food [64]. The use of stormwater in rain gardens for food production is regarded as a win-win solution, shielding waterways from stormwater, and enabling food production, which otherwise may be restricted. The production of vegetables through irrigation with potable water may facilitates a concrete earning and saves time devoted to building a rain garden. In purposefully built rain gardens, vegetable production was assessed. A similar vegetable yield was produced as a parallel control, utilizing traditional watering methods for vegetable gardens. The infiltration-type rain garden reduced both the volume and frequency of runoffs by more than $90 \%$ and sized $7.5 \%$ of the drainage area. These findings indicated that it is feasible to produce a suitable yield and withstand the purpose of rain gardens in decreasing urban runoff loss into the sewer system. The harvesting of ecosystem services from rainwater in India was estimated [65]. Researchers observed that, having a rooftop garden area of $21 \mathrm{~m}^{2}$, water irrigation supported the production about 3 and $1 \mathrm{~kg}$ of tomatoes and lettuce, respectively. Another study reported in Michigan in the same way that the production of food from GRs was obtained from irrigated crops such as tomatoes, cucumbers, pepper, basil, and green beans [66]. Their results indicated that all tested plants produce enough yields except pepper and thus suggested a useful way for crop production from GRs. In addition, they found that the proper management, selection, and type of vegetables can be a more useful indicator for healthy food production in extensive GR.

\subsubsection{Energy-Food Nexus}

Vertical hydroponic farming (VHF) proposes beneficial impacts than conventional farming such as efficient water and land usage as well as the reduced transport cost (if performed in urban areas) [67]. In the same way, a comparative study of VHFs and greenhouse in the Netherland and Dubai indicated that the energy usage was efficient in VHFs per $\mathrm{kg}$ food, while acquired energy was much higher than solar energy of greenhouse [68]. In addition, urban rooftops can provide PV-green roofs for food production which effectively utilize rooftop areas as well as reduce $\mathrm{CO}_{2}$ emissions linked with food transport to urban areas $[69,70]$. There is a need for thorough investigations on the selection of urban agriculture plants, such as fruits or vegetables, by knowing the climate conditions and geographical locations [71]. In Morocco, an experimental study installed a PV system (10\% roof area) on a tomato garden. Their results indicated no differences in the tomato yield by the PV system on the rooftop [69]. The above outcomes proposed that this process facilitates sustainable practices in the modern agriculture system. A PV system not only reduces costs on transportation linked with food supply, but also makes use of empty areas on an urban rooftop.

\subsection{Three Node Nexus}

\subsubsection{Food-Energy-Water Nexus}

As a new paradigm of multiple functions of food-energy-water nexus, a full-scale $\left(840 \mathrm{~m}^{2}\right)$, concave GR (which consists of a vegetable garden, flower garden, and a fish pond) was compared to a normal roof are compared on the \#35 building in Seoul National 
University, Seoul, Korea [45]. To investigate the potential effects of urban runoffs (flood) mitigation, a concave green roof (GR) system was developed which stores and retains rainwater in urban soils. In this concave GR system, $140 \mathrm{~m}^{2}$ area displayed the impacts of runoffs (flood) mitigation in the form of reducing storage of rainwater (6.7 tones), delay in peak time $(3 \mathrm{~h})$ and quality of peak flow $(56 \%)$. To examine the mitigation effects of urban heat island (UHI), a temperature different of about $24{ }^{\circ} \mathrm{C}$ was observed in comparison with normal roofs. For producing food in urban agriculture, GR $\left(420 \mathrm{~m}^{2}\right.$ area) was managed for more than 30 households. In this type of roof garden, multiple crop types, such as vegetables, fruits, and root crops, can be obtained. These outcomes can greatly contribute towards boosting food security and societal development [45].

Similarly, underdeveloped countries mostly suffer due to lack of sewage water treatment and the pollution of blue (water) bodies, and yet few GBIs (for example., urban treatment wetland) could be used for wastewater treatment [51]. Further, the usage of untreated water for irrigation of cultivated crops is being implemented globally [72]. According to Avellan et al. [73], hypothesis the $200 \mathrm{PE}$ community, swage from the constructed wetland (CW) might generate 11-52 $\mathrm{m}^{3} /$ day for irrigation. Supposing no contribution of rainfall, and these amounts could irrigate $0.2-1.1$ ha of maize crops, with a projected yield of 750-3500 kg of grain/season [73]. Dry lands may essentially only be capable to support tiny wetlands per unit population. Therefore, if local communities can have committed to the nexus approach, water devoted to irrigation, and a certain amount of undrinkable water resources could be used to enlarge untreated water and enhance their wetland size per capita, thus enhancing the availability of nutrient, energy, and water resources. On the other hand, the availability of CW land may become limiting due to wetland size increases and communities will require optimization for contending land uses. However, the nexus approach can give a framework to examine community choices for resource recovery and conservation [74].

In addition, VHF offers various benefits over traditional farming. Also, the social benefits of urban green areas have the skill to move city farming nearer to resident's centers and improve local spaces, VHF can offer various improvements to growth efficiency and resource usage [75]. A study into the yield and resource (land, energy, and water) usage of lettuce agriculturalists in Yuma, Arizona, USA revealed that hydroponic farming mitigates water consumption by $13 \pm 2.7$ times as compared to traditional farming [76]. The water usage for both approaches was roughly comparable over an equal area, but in that certain area, the yield is increased, because of vertical stacking growing beds and reduced harvest cycle times, which make hydroponic farming more effective by these metrics. The scholars therefore note that, by their outcomes, hydroponic farming is not yet a fully sustainable replacement. This comes commonly from the enhanced electricity cost associated with heating and, specifically in Arizona, USA, where cooling electricity costs of indoor farms, that took up (14\%) of total energy used in the summer (July and August) months. As a result, the energy used in VHF was different, namely orders of magnitude greater than traditional farming. Together, these highlights indicate that energy consumption is the main area for improvement in the efficiency of VHFs and revealed how assimilation to district heating systems can extremely lower the running energy costs of such kinds of farms, and make them more economically sustainable.

\subsubsection{Food-Energy-Waste Nexus}

Urban centers create a heat island effect because of the lack of greenery. Another problem is food safety, security, as well as availability and cost-effectiveness due to poor urban agriculture planning. A third concern is the amount of waste that people generate. This waste pollutes natural resources, ground water, and the air in their surroundings. The proposed solution is the implementation of a rooftop garden in urban areas. For example, some researcher evaluated green roof as a mean to use recycled waste and $\mathrm{A} / \mathrm{C}$ condensate water and to calculate temperature variation in buildings [77]. This study, based on a rooftop garden with six wood boxes, proved that it was possible the local production of 
food (e.g., radish total weight $(3581.3 \pm 188.2$ and $1976.9 \pm 440.1 \mathrm{~g}$ ) and romaine lettuce total weight $(64.2 \pm 19.5154 .2 \pm 59.0 \mathrm{~g}))$. Moreover, this solution decreased the temperature variation under the roof, allowing the usage of recycled waste and potentially enhancing reptile, insect, and avian biodiversity. Furthermore, results showed that the productive consumption of $\mathrm{A} / \mathrm{C}$ condensate (each garden box was watered every other day with $5 \mathrm{~L}$ ), which reduces the extra burden on water and would doubtless improve city environmental conditions, mitigate summer UHI effects, and decrease the material going into the landfills as well [77]. Many residents do not reuse A/C condensate in Lebanon (unpublished data) and other developing countries. Therefore, wasted resources could be used very productively but little investment is required. Further, this kind of activity can make social community development and contribution to the local inhabitant food security. Many innovative and creative events could also be possible at the GR by the community.

\subsubsection{Water-Soil-Waste Nexus}

Water supply, agriculture resource management, energy production and pollution control have been treated conventionally as independent problems to be solved individually. The interconnections among water, energy, and nutrients cycle can be exploited as a system now, that performs many functions enhanced to provide services for the human communities. The urban treatment wetland could be a common thread that generates the water-soil-waste (WSW) nexus in a community. For instance, Avellan et al. [51] studied the role of wetlands for the production of biomass within the WSW nexus. They indicated that wetland biomass provided energy that can offset environmentally damaging sources. On a small scale, the dried biomass can be combusted as a cooking fuel source. More complex biogas reactors, economically feasible with $\mathrm{CW}$ biomass feedstock could improve energy security when extra organic sources are consumed. Further, the waste product conversion into an energy resource can be a perfect strategy in a water-energy cycle.

By using the outcomes from our finalized scientific literature, we identified the most normally reported GBI types and their features that matched our research. As shown in Figure 1, these locations are found across a wide array of contexts (i.e., countries, regions, urban land uses, and climates). In addition, we use the scientific literature to identify the main ecosystem services and disservices associated with different GBIs in Table 1. 
Table 1. Relationship between different GBIs typologies, FEW nexus and services provided to humans. Values in last right side cells shows number of total publications that showed Positive (ES) and negative (Edis) effects on FEW.

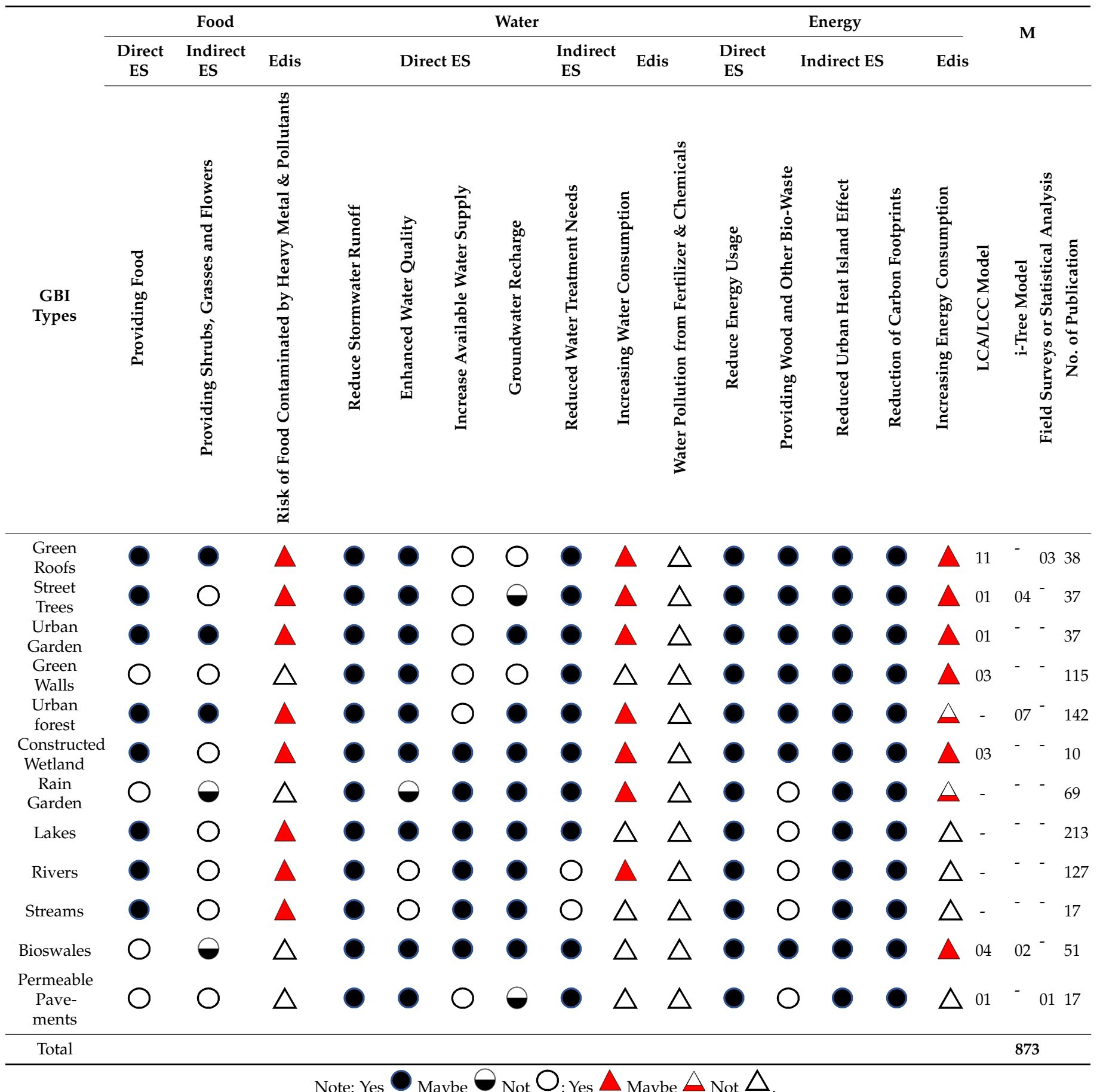

\section{GBI-FEW Nexus Modeling Methods}

The GBI-FEW nexus has gained much attention in research communities. Research relevant to the calculation of flows and the dependencies between different resources, quantifications of system performance, evaluation of technology, and policy application have been conducted to develop administration options and apprehend their interlinkages. There are various methods for the nexus research. However, research priorities, aims, scales, and data availability are critical to decide which approach should be used for the GBI-FEW nexus researches. Moreover, no single approach is applicable for all situations [78,79]. 


\subsection{Field Surveys and Statistical Analysis}

Field surveys and statistical analysis of public data released by local governments and agencies are widely used to explore the relations among nexus sectors. Global energy production supported about $15 \%$ of global freshwater water extraction and approximately $70 \%$ of total global water used for food production [80]. Through a household field survey, the benefit of products derived from trees for 450 homes in poorer built-up areas of three big towns in South Africa [81]. This study showed that $91 \%$ of homes burned wood, normally purchased or collected from the urban fringe, while one third firewood was collected from their household plot trees. Most commonly, 98\% fruits were purchased from different sources. However, half of the surveyed population supplemented this supply via harvesting fruits from a city home plot. Another study focused on the wetland ES of Colombo city, Sri Lanka [82]. It was proven that natural remedies, fresh water, and food were the main provisioning ecosystem services.

Such approaches are very useful to capture main factors-for example, land-use changes, climate change, demographics - which dominate the evolution of the GBI-FEW nexus system. Through questionnaire responses across each respondent, the relevance of different factors that may affect the FEW nexus system was ranked [83]. Based on such ranking, specific recommendations to increase the sustainability of each sector were derived. Existing studies proved the relevance of qualitative approaches in detecting the complex interactions among nexus sectors [83,84]. Furthermore, the analysis of different variables at multiple scales paved the way for an integrated nexus modeling and assessment [85]. However, statistical methodologies should be integrated with an assessment of FEW system dynamics to provide policy makers and planners with more insights into an internal mechanism of relations between food, water, and energy, resulting in great troubles in policy evaluating and making.

\section{2. $i$-Tree Eco Model}

i-Tree is a most widely employed, tested and free model, developed by the United States Department of Agriculture Forest Service and introduced in 2006 [86]. We observed that i-Tee model mostly used for urban forest ( $58 \%$ ), followed by street trees $(42 \%)$ ecosystem (Table 1). This model, embedded in a set of computer tools, estimates the ES and values of urban trees globally (www.itreetools.org, Accessed Data: 1 January 2021). i-Tree Eco model uses input data of forest structure, weather, buildings, air pollution, and economic pricing to quantify the tree-based ES of avoided water runoff, building energy savings, air pollution reduction, and carbon storage and sequestration [87]. Soares et al. [88] evaluated the cost and benefits of street trees by using $\mathrm{i}$-Tree model. The result of this study indicated that each tree intercepted $4.5 \mathrm{~m}^{3}$ rainfall annually, and this service was valued at $\$ 48$. Further, the value of energy savings was $\$ 6.20 /$ tree, and the effects of urban street trees on building energy performance were based on software simulations which incorporated climate, building, and shading effects [89]. The tools can be applied anywhere in the world. For example, Kiss et al. [90] applied the model to estimate air pollution and carbon sequestration which is based on the ecological processes of park and street trees in Szeged, Hungary. Moreover, the model has some limitations. For example, application of the i-Tree Eco tool was limited to yearly average analysis because of the difficulty in finding correct and higher temporal resolution samples, such as daily, seasonal, or annually [91]. Further, it does involve field surveying (more time required if it is large scale research) and data interpretation. Therefore, the next basic steps in model improvement should include model accuracy, extended sensitivity tests, and uncertainty analysis. In future, the model will be useful for other urban ecosystem (e.g., bioswales, CTW etc.) and ES, such as the estimation of food, noise, etc., due to its continuous development.

\subsection{Life-Cycle Analysis}

Life cycle assessment (LCA) is the most important and widely used standardized approach for calculating the environmental impacts of a given process or product through- 
out its whole life cycle. It can easily export its measurable processes and correctly show the quantification of any unit during its life cycle, with the features indicating all the values - inputs or outputs-which may have significant effects on the environment [92]. Because of the above benefits, the LCA methodology, which could provide environmental data and consistent analytical framework support the managers for decision making, has been widely implemented in evaluating the environmental effects of nexus sectors across their consumption and production processes, purpose to find an efficient solution to cope with present resources shortage and world climate change.

It is clear from this survey that the utilize of LCA is widespread as an appraisal tool. We found that this technique mostly used in various GBI systems (e.g., GR (46\%), followed by CTW (17\%) and rain gardens (13\%)), as shown in Table 1. A number of studies have been conducted to compare the ecological performances of the GBI infrastructure with traditional infrastructures by using LCA approach [93-100]. Kosareo and Ries [101] compared the extensive green roof and intensive green roof to traditional gravel ballasted roofs in Pittsburgh, USA by using LCA method. Result shows that vegetative roofs were the finest environmental option because they enhance roof life and decrease energy demand. In addition, few studies reported that rain garden is more environmentally and financially favorable than the old-style infrastructure in stormwater management [102,103]. Therefore, the ecological performances GBIs, particularly the nexus of food, water, and energy have rarely been measured from life cycle perspective. Though each kind of GBI remains an irreplaceable city element for generating ES. A comprehensive investigation of ecological performances will be beneficial in improving the application of these GBI infrastructures in municipalities with limited resources. Further, relevant information should be delivered to city managers, investors, and designers that can help to design the GBI strategies, because it can maximize their ES while decreasing their ecological impacts from construction to usage and to disposal.

Yet, the LCA approach has still some limitations despite its broader application in nexus study. Because of high dependency on data, the LCA technique is difficult to adopt in data-scarce areas [104]. Such inadequacies can be overcome by utilizing LCA combined with other techniques such as material flow analysis [105]. Furthermore, because of the personal judgment of the definition concerning the system boundaries, therefore it is unavoidable to leave out few production processes, which frequently leads to important truncation errors in some calculations of LCA. Further, this approach looks to be a static technique and may not be directly suitable for the dynamic analysis of complex systems [92]. To some extent, it is difficult to contemplate social factors inside the coupled system based on the LCA technique with the focus on an evaluation of environmental impacts [106]. Future research will mainly focus on a complete LCA (including the use like energy consumption, food production, and water retention and usage, etc.) and the end-of-life phases.

\section{Discussion}

\subsection{Positive and Negative Impacts of GBI on FEW}

In this segment, we describe the most important city GBI types and the associated FEW topics that are found in a systematic literature review. We observed that scientific studies on GBI-FEW nexus related primarily focus on direct and indirect ES (e.g., food), because of food security issues in cities. Many studies on the direct positive effects of urban farming on food generation in built-up places or food-associated topics are receiving attention in the scientific literature. Some GBI types (such as green roofs, urban gardens, urban forests, etc.) can be used for food generation, as shown in Table 1. For example, the rooftop gardens are favored in dense urban cores with limited space, and different kinds of vegetables can be produced and make the people self-resilient for local food production. Nowadays, societies in developed and developing countries normally depend on urban agriculture to meet their demand for food. Orsini et al. [107] inquired about the production capability of rooftop farming in Bologna, Italy, finding that rooftop farming 
could provide more or about $12,000 \mathrm{t}$ /year of vegetables to Bologna, satisfying $77 \%$ of the city dwellers' requirements. A Singaporean annually consumes $82.6 \mathrm{~kg}$ average of vegetables [108]. According to Singapore Statistics [109], the population of Singapore is 4.8 million, Singapore requires 396,480 t/y of vegetables. Both traditional farms and rooftop gardening can however satisfy approximately $35.5 \%$ of Singapore's vegetable requirements, and significant growth from the (5\%) currently met as well [8]. Similarly, few authors observed that the urban gardens also play a crucial role in food security and the supply of food in several historical periods, and the importance of gardens enhances in the urban areas for food security during political and economic crises [110]. McClintock, [111] studied in the USA and Europe, the provision of urban food production by gardens formed a part of adaptation approaches in times of battles. When Sweden was influenced by a severe shortage of food during World War II, $10 \%$ of the food utilized in the whole country came from urban gardens [112]. In addition, the contribution of city gardening to the urban food supply was evaluated in Salzburg, Austria. The results indicated that out of 156 city gardeners, $76 \%$ cultivate their vegetables and fruits, the majority of gardeners providing $44 \%$ of their vegetable utilization and $10 \%$ of their annual fruit [113]. Urban agriculture practices can not only satisfy the vegetables and fruits requirements of the urban dwellers but decrease the food imports as well, whereas also reducing annual carbon emission footprint. For instance, Lee et al. [114] demonstrated that for the greater municipal area $\left(51 \mathrm{~km}^{2}\right)$ of Seoul, South Korea, an urban agriculture implementation would decrease by 11.7 million kg carbon dioxide emissions annually. This offset amount is the same value of annual carbon dioxide sequestered by $10.2 \mathrm{~km}^{2}$ of 20 -year-old oak forests and $20 \mathrm{~km}^{2}$ of pine forests. Hence, there is a need to develop a sustainable policy to maximize the positive effects and minimize the negative effects of urban agriculture.

In addition, the city street trees provide food (fruits) as well. However, the fruit tree species with normally known edibles, like pears, cherries, and apples were not offered and remain prohibited in city street planting strips. The reasons for prohibiting these three species is that their products (fruits) are the probable falling of fruit on the footpath and enhanced risk of walker injuries [115]. Secondly, the consumption of urban planted fruit trees poses little risk of heavy metals (e.g., cadmium and lead) exposure [116,117]. Therefore, suitable species for growing in the street tree strips included dogwood and serviceberry, which produce a fewer edible fruits. The Food and Agriculture Organization of the United Nations (indicated as FAO) evaluated that one-third of the global food production (around $1300 \mathrm{t}$ ) is wasted or lost [1]. Food loss refers to the reduction in food quality and quantity, throughout the several stages of a supply chain; from agriculture production to consumption and ultimately food disposal (before recycling) while it is known that there might be up to 11-stages of supply chain waste [118]. If we could save only one-fourth of the food which is currently waste or lost around the globe, it could be enough to feed all undernourished people [119]. All of these above resources could be used to enhance food generation, or to influence the food system in other ways. Therefore, associated with this motive is a particular one based on the future requirements for food and the growing global food supply.

The scientific literature shows that GBI not only generates ES, but also ecosystem dis-services. However, the same urban GBI can have a positive and negative effect on, e.g., food (Table 1). On one side, growing their food in a metropolitan area, ensure a food supply especially for the poor people in developing countries. In contrast, the safety of food turns out to be a major concern because of environmental pollution [120,121]. For example, heavy metals become the main problem sourced from gaseous atmospheric deposition [122,123]. Furthermore, wastewater reuse in the urban agriculture sector whereas improving city water system efficiency, adds to significant concerns about the safety of food with pathogens moving from sewage water to food [124]. Similar to another farming system, urban agriculture itself may also contaminate water with pesticides and fertilizers [125]. Hence, unintentional negative impacts of each GBI must be taken into account, as this can offset 
the objectives that motivate the expansion of GBI in cities. Therefore, its existence as a green infrastructure also helps control rainwater runoff to lessen the risk of flooding.

Blue infrastructure studies are also common as their green counterparts. We found that the effects of the urban rivers on reduced stormwater runoff, energy-saving, and improved water supply are the topics $(24 \%)$ mostly discussed in the literature, followed by CTW (17\%) and streams (15\%) topics (Table 1). Some blue infrastructures (such as rivers, CTW, lakes, etc.) studied in the scientific literature demonstrate associations to at least one subject in each of the FEW systems.

Furthermore, crop cultivation needed a considerable amount of water. To produce a kilogram of tomatoes by using conventional land cultivation approaches, 200-400 L of water is essential. Hydroponic farming, therefore, requires around four times less water for the same yield [126]. As an estimation, the amount water needed for each $\mathrm{kg}$ of vegetables harvested in soil culture is assessed to be $200 \mathrm{~L}$ [10]. This explains to $50 \mathrm{~L}$ amount of water essential in the case of hydroponics farming. To meet this demand, various strategies for water harvesting are considered, the first one is rainwater harvesting and secondly grey water consumption via GR and CW. For instance, in Singapore, the local rainfall is $2360 \mathrm{~mm}$ annually [127]. Taking into account the total Housing and Development Board apartments (HDB) residential area in new towns of Singapore- the total catchment area is 7435 ha [128] - could contribute to a collection of about $175 \mathrm{~mm}^{3}$ stormwater annually. Thus, it indicates that around 25 times more water could be available than the water required for urban rooftop in HDB estates, suggesting that urban stormwater harvesting can be a sustainable strategy. Moreover, the integrated wetlands usages would be the contributions to conserve water resources as well. Being an essential medium for living things, water is necessary for both aquaculture (fish) and agriculture (crops) production processes. With food production, the integrated wetlands would greatly support water storage and the population to become more self-sustained with enough water provide for the production process.

Globally, $80 \%$ of all untreated water is released into the ambient environment without any treatment and around 1 billion people still practice open defecation [74]. Constructed treatment wetland (CTW) is capable to utilize the natural function of soil, micro-organisms, and vegetation for the treatment of wastewater (e.g., rainwater runoff, domestic or municipal sewage), proving that it is a cost-effective and well-established approach [129]. The most important benefit of CTWs for sewage water treatment might be their ability to offset GHG emanations, to generate energy [130]. Biofuel production through the integrated wetland is a sustainable approach that can provide compounded assistance and benefits to developing countries towards energy and food security [131]. Liu et al., [130] have been predicted that if CTW treated all of China's wastewater, a land area $\leq 20 \%$ of fallow land in China would be essential and could annually generate bioenergy $\left(8.2 \times 10^{7} \mathrm{GJ}\right)$ sufficient to meet the electricity demands of about 2 million homes in China [132]. Therefore, the utilization of CTW to treat sewage water presents an alternative to old-fashioned activated sludge systems, conserving energy expenditures to treat the sewage water and generates a bioenergy resource [133].

In the interim, energy is the subject that presents the most prominent assortment of GBI sorts. Thinks about on energy subjects too appear direct and indirect positive impacts on their related ES. The green infrastructure, e.g., urban gardens, GR, street trees, and other vegetation, can help to reduce local temperature (Table 1). These influences on temperature are due to evapotranspiration and shading of urban surface mechanisms $[134,135]$. When these infrastructures are over/near to buildings, they have an even larger impact on microclimate, diminishing the artificial cooling requirement and contributing to energy savings indirectly $[121,136]$. Urban trees and forest also have the potential to capture and store carbon, as highlighted by the literature $[137,138]$, as well as to reduce city run-off and flood control [139]. By urban agriculture, energy can be reduced or saved from avoided mileage of food, also from avoided cooling and packing activities. Few authors suggested that urban agriculture has the potential to be a more environmentally damaging food 
source as compared to conventional agriculture, generally because of energy-related effects related to greenhouses operation [140]. Nonetheless, gains in energy efficiency could be realized through the co-location of UA operations with waste streams [141]. Moreover, green infrastructure not only reduce temperature and save electricity but also decrease energy cost and GHGs emission, that is generated in term of electricity production. Yet, there is a need to find an integrated nexus framework that takes all trade-offs and each GBI indirect effect into account.

Similarly, we talk about how blue infrastructures, like wetlands, can be cooler than non-wetlands areas which have been confirmed in many studies [142,143]. Intensive evaporation from urban wetlands could elevate air humidity and after that lessens the temperature of neighboring areas [144,145]. The results of the latest study reported that air temperature near wetlands getting decreases by $2.74^{\circ} \mathrm{C}$ as compared to neighboring areas [146]. Furthermore, positive or negative effects from blue spaces on human health must be examined from the overall socio-ecological context of specific urban areas [4]. For instance, waterbodies in temperate low humidity climates have positive impacts like local temperature reduction. In hot humid climatic cities, the water increases moisture, has minute effects on temperature but overall human thermal comfort decreases. Many other unintentional negative effects may arise as well, e.g., utilization of sewage water for urban gardens irrigation [147], as well as from the increase of mosquito-borne diseases that can be exacerbated by GBI [148].

In addition, garden waste biomass is a potentially underutilized renewable biofuel feedstock, which is increasing dramatically with rapid urbanization worldwide. Few authors have suggested that garden waste for energy generation could be more environmentally friendly $[149,150]$. We are conscious of two studies that have been carried out on assessing the potential of city waste (garden) for biofuel production. The biofuel production from city waste (garden) can offset 1.6-6.5\% of the metropolitan transportation gasoline demand of Singapore [151]. According to another study that has been carried out in China, the total possible biofuel generated by garden waste was calculated 260 petajoules (PJ), accounting for $12.6 \%$ of the Chinese transportation gasoline demand, or $20.7 \%$ of China's city residential electricity consumption in 2008 [152]. Therefore, the garden waste for biofuel generation enhances energy yield, as well as decreases waste disposal cost. Similarly, garden waste in the urban area is more suitable for energy generation because it has already been collected and transported and has no impact on the stability of the natural ecosystem. The feasibility and potential of using garden (e.g., community, GR, etc.) waste for energy generation should be researched further.

Where urban garden biomass provides positive effects, oppositely it also generates some negative effects. So, urban farming is commonly connected with heavy water consumption, specifically during periods of dry climate. The ratio of potable water consumed for the garden (domestic) escalates with increased dryness. Syme et al. [153] study in western Australia and indicates that $56 \%$ of local water consumed is connected with the garden (domestic). Another study in Barcelona, Spain; support the above research and they found that the $30 \%$ (average) local water consumed within the garden, and increases up to $50 \%$ during the summer [154]. Similarly, changes in urban climate will enhance the demand for water for gardens in temperature areas. However, surprisingly, some studies have examined the detail of this. There is a need for scientists to think of some innovative solutions for the reduction of water usage in arid climate areas. For example, mulching flower beds reduces moisture evaporation as well as limiting GHGs emissions [155], and organic lawns versus the intensive way of turf management could minimize water use up to 10-fold [156]. In the future, further research is essential to fill this research gap.

In a city environment where the availability of ground surface is limited, roofs offer considerable space for the application of urban heat island (UHI) mitigation strategies. GRs are efficient in reducing the level of building energy consumption and decreasing the variation of indoor temperature both in cold and warm climates [14]. Therefore, the future plays a very important role in the potential contribution of GRs. In warm climates, the GRs 
possibly decrease indoor temperature via preventing the direct effect of solar radiations and shading the roof top layer $[157,158]$. For the climates of subtropical regions, the extensive GRs have great potential with strong rain and high temperature. Niachou et al. [159] stated that the GRs in Greece decrease the energy consumed for cooling by $2-48 \%$ depending on the space covered by the GR with indoor temperature decreasing up to $4 \mathrm{~K}$. Meanwhile, in different climates, approximately the same results were estimated with maximum cooling saving by $4 \%$, heating saving by $9 \%$, and total 3\% energy saving with GR retrofit [160]. So, GRs can mitigate the surface temperature, improving the surrounding environment of an area.

GR is successfully applied in the city of South Korea for surface temperature and rainwater runoff reduction [161,162]. However, in South Korea, a major issue is the water quality of GR is degraded after a while. This is due to the excessive usage of pesticides and fertilizers in the GR. However, it is essential to share information with each inhabitant for the planning and management of the GR to obtain the multiple benefits $[163,164]$. Because of very limited studies, the GBI stakeholders and owners are not aware of the GBI advantages in underdeveloped countries. It is essential to provide information related to the benefits of the GBI to the stakeholders and owners and to encourage the implementation of GBI. Consequently, the GBI is the appropriate choice to enhance the water quality in urban areas.

\subsection{Changes in Tradeoffs and Synergies of FEW Nexus in GBI}

Even with the progress in ecosystem services (ESs) studies, we still lack a comprehensive and satisfying understanding of the feedback and interactions among several ESs $[165,166]$. They might both impair and support each other, which suggests an existence of a range of trade-offs and synergies [167]. Here, a trade-off discusses the rise of the provisioning of one service and the simultaneous decrease of another ES at the same place. This knowledge finds an obligatory application of the ESs concept in political and social decision making in terms of estimating whether it is sustainable, resource and cost-efficient, or worthwhile to support the provision of one service to a probably costly decreasing of another ES [168,169]. This is especially true in urban areas, where nowadays more than half of the global population lives, and this is projected to increase [170]. In recent years, metropolitan ecology has made considerable progress concerning the particular ecological functions in city areas and the unambiguous consideration of city ESs, although their contact with one another has not still received much study.

Trade-off identifications allows policymakers and managers to understand the hidden penalties of preferring one ESs to another. Building-integrated agriculture (indicated as BIA) is another type of horticultural production in municipalities, consisting of the implementation of high performance without soil cultivation approaches modified for use on the top of or within buildings [171]. Benis et al. [172] considered a more advanced "high-tech" RG farm, and the high productivity of conditioned GHs has led to the positive net present value (NPV) in both long food supply chains (LFSC) and short food supply chains (SFSC) cases. This product has to be scrutinized, as distributing such huge amounts of produce may need widening the disposal zone, leading to a not-so-domestic food system where the food could travel longer distances, needing conditioned storage, and ultimately ending up being harmful more to the environment in comparison with rural produce which travels to the town. To evade this pitfall, vegetation diversification can be a beautiful solution. Most importantly, rooftop greenhouse (indicated as RG) plantation has been gaining fame recently, and some have adopted this approach in big cities such as Singapore, New York, and Montreal, selling food baskets (including different quantities and kinds of fresh produce locally) to their subscribers [172]. Eventually, this model has the potential to locally meet the substantial demand of urban inhabitants for vegetables. However, the installations of "high-tech" RG farms are generally equipped with thermal screens, rainwater harvesting systems, backup lighting, and climate control systems. While higher investment cost and higher energy requirements as compared to conventional horticulture 
facilities were recognized as main limitations to the extensive application of conditioned RG farms [140,173]. According to Benis et al. [172], global warming potential (indicated as GWP) reduction per square meter of urban rooftop result is negative, which mean that "high-tech" RG farming is more injurious to the ambient environment when compared (in terms of area/land) to another productive use of rooftops. This is because of the huge amount of energy requirements for controlled-environment cultivation. In a previous publication where different BIA tomato forms were compared to the existing conventional supply chain in Lisbon [174], conditioned RG farming was found to possibly cut $\mathrm{CO}_{2}$ emanations in half. In a currently published life cycle analysis (indicated as LCA) of the Lisbon Municipal Area food system, the supply chain of vegetables was estimated for a Land Use of $23.4 \mathrm{~m}^{2} / \mathrm{cap} /$ year [175]. The integration of agricultural and horticultural production into or within buildings needs no extra land because the land has already been occupied by the urban buildings. One can, however, hypothesize that both BIA and building-integrated photovoltaics (indicated as BIPV) may lead to ecological benefits by lessening the demand for agricultural land and decreasing land effects from the fossil fuel developments, subsequently improving biodiversity and restoring habitats. Modelling an economic valuation of these trade-offs is a challenging task since the environmental services provided by soils are not priced in the markets [176]. The urban rooftop garden is a good solution for producing agricultural products and mitigates the city land, simultaneously GHGs emissions into the atmosphere may cause a global warming issue. So, policy makers and urban managers must also think about these significant tradeoffs that are not suitable for cities. They must adopt innovative ideas that minimize the changes in tradeoffs and produce a synergic effect at a small urban agriculture scale.

In addition, GBI also allows experts from various sectors to account for trade-offs and synergies between the services for which each sector is responsible. For instance, vacant land might be managed as a useful food landscape, as a wildlife habitat, or for heavy rainwater management $[177,178]$, which depends on who takes headship in management. On the other hand, from brown to green GBI, not all transformations result in the same ES. For instance, urban agriculture could provide food and habitat for pollinators [179], but the application of fertilizers, pesticides, and soil amendments by the hobby gardeners [180,181], may degradation downstream water as compared to increasing quality of water via rainwater retention. Moreover, Sanchez et al. [182] undertook a study on arid land, constructing a treatment wetland, and the result shows that the wetland reduced the nutrient well from surface water and another surprising ES is a significant habitat for aquatic wildlife (such as birds). In contrast, a huge volume of water is lost to the atmosphere through plant transpiration, which is unusually high during the dry and hot season in the Sonoran Desert. The GBI concept allows different stakeholders (e.g., food policy committees, domestic water quality authorities) to talk to each other about how a parcel can be used to maximize the benefits whereas avoiding damaging trade-offs. This is already in practice in Strasbourg: The city's Urban Ecology and Water Department (UEWD) worked with local communities and scientists regularly to design and applied the restoration of the Ostwaldergraben [183].

McDougall et al. [184] have been investigated that the inputs and produce yields over a one-year duration in 13 small scale gardens and organic farms in Sydney, Australia. The result of this study showed that the average yields by $5.94 \mathrm{~kg}$ per meter square, which is about double the yield of conventional commercial Australian vegetable farms. Whereas these systems utilized the land effectively, but they were relatively ineffective in their use of labor and material resources. To ensure the sustainability of urban agriculture production through the cost of inputs is very important to find the tradeoffs essential to attain high yields. Both issues could be reduced with more judicious resourcing of materials such as organic matter and water. These resources are comparatively abundant in urban environments and are frequently underutilized to the point that they are treated as waste. 


\section{Conclusions}

The interactive flows in the energy, water, and food system as a food-energy-water (FEW) nexus are very important for the sustainable development of cities, and they can be arbitrated via green-blue infrastructure (GBI) in the built-up area. Here, our focus is on non-built "nature in cities" infrastructure. In particular, we provided an inclusive scientific literature review to study how GBI influences the FEW nexus in urban areas. The GBI generates multiple ecological benefits (food production, water and energy-saving, and microclimate regulation) in urban centers. The FEW flows also generate some negative effects (dis-services) within the GBI, for example, food products within the green-blue system, but over-application of pesticides and fertilizer, could generate a release of toxic substances, that might also alter the quality of water. If water is extracted to produce energy, it might reduce the natural water flow within a river, impacting on the biosphere too. Well-planned urban construction can help to control the negative effects.

There is a need to make integrative and deliberate policy to link the GBI with each element in the urban FEW nexus. Current research also focuses on nexus modeling techniques in terms of their benefits, drawbacks, and applications. Moreover, guidance is provided on the choice of an adequate modeling approach. Finally, water, energy, and food are linked physically, but tradeoffs among them often increase when their management is put into practice. We must minimize the tradeoffs and build-up synergies between food, energy, and water by using a holistic approach. Therefore, the GBI-FEW nexus has become a major approach to address the relation between three important individual resource components of sustainability.

Supplementary Materials: The following are available online at https:/ /www.mdpi.com/article/10 .3390/en14154583/s1, Table S1: Food, energy and water topics associated to urban GBI topics.

Author Contributions: Conceptualization, G.L.; methodology, A.M.S., G.L. and M.C.; resources, F.M.; data curation, Q.Y., J.X., S.D. and R.P.; writing—original draft preparation, A.M.S., G.L. and M.C.; writing—review and editing, A.M.S., G.L. and M.C.; supervision, G.L.; project administration, G.L.; funding acquisition, G.L. and F.M. All authors have read and agreed to the published version of the manuscript.

Funding: This work is funded by the National Natural Science Foundation of China (No. 52070021), the Belmont Forum (No. NEXUS2016: 152), the JPI Urban Europe (No. 11221480), the NSF, USA (No. 1829224) and the 111 Project (No. B17005).

Institutional Review Board Statement: Not applicable.

Informed Consent Statement: Not applicable.

Acknowledgments: Marco Casazza gratefully acknowledges the scholarship received by the Department of Sciences and Technologies of the University of Napoli "Parthenope" (DD 2/2021).

Conflicts of Interest: The authors declare no conflict of interest.

\section{References}

1. United Nations. UN World Population Prospects: The 2017 Revision; Population Division, Department of Economic and Social Affairs: New York, NY, USA, 2017.

2. Huang, K.; Li, X.; Liu, X.; Seto, K.C. Projecting Global Urban Land Expansion and Heat Island Intensification through 2050. Environ. Res. Lett. 2019. [CrossRef]

3. Simpson, G.B.; Jewitt, G.P.W. The Development of the Water-Energy-Food Nexus as a Framework for Achieving Resource Security: A Review. Front. Environ. Sci. 2019, 7, 8. [CrossRef]

4. Haase, D.; Larondelle, N.; Andersson, E.; Artmann, M.; Borgström, S.; Breuste, J.; Gomez-Baggethun, E.; Gren, Å.; Hamstead, Z.; Hansen, R.; et al. A Quantitative Review of Urban Ecosystem Service Assessments: Concepts, Models, and Implementation. Ambio 2014, 43, 413-433. [CrossRef] [PubMed]

5. Barbosa, A.; Martín, B.; Hermoso, V.; Arévalo-Torres, J.; Barbière, J.; Martínez-López, J.; Domisch, S.; Langhans, S.D.; Balbi, S.; Villa, F; ; et al. Cost-Effective Restoration and Conservation Planning in Green and Blue Infrastructure Designs. A Case Study on the Intercontinental Biosphere Reserve of the Mediterranean: Andalusia (Spain)—Morocco. Sci. Total Environ. 2019. [CrossRef] [PubMed] 
6. Benedict, M.A.; McMahon, E.T. Green Infrastructure: Linking Landscapes and Communities; Island Press: Washington, DC, USA, 2012.

7. Roberts, D.; Boon, R.; Diederichs, N.; Douwes, E.; Govender, N.; Mcinnes, A.; Mclean, C.; O’Donoghue, S.; Spires, M. Exploring Ecosystem-Based Adaptation in Durban, South Africa: "Learning-by-Doing" at the Local Government Coal Face. Environ. Urban. 2012. [CrossRef]

8. Astee, L.Y.; Kishnani, N.T. Building Integrated Agriculture Utilising Rooftops for Sustainable Food Crop Cultivation in Singapore. J. Green Build. 2010. [CrossRef]

9. Childers, D.L.; Bois, P.; Hartnett, H.E.; McPhearson, T.; Metson, G.S.; Sanchez, C.A. Urban Ecological Infrastructure: An Inclusive Concept for the Non-Built Urban Environment. Elem. Sci. Anthr. 2019, 7. [CrossRef]

10. Hoekstra, A.; Hung, P. Virtual Water Trade a Qualifation of Virtual Water FLows between Nations in Relation to International Crop Trade; Value of Water Research Report; IHE: Delft, The Netherlands, 2002. Available online: https:/ /www.waterfootprint.org/media/ downloads / Report11.pdf (accessed on 21 June 2021).

11. Mullaney, J.; Lucke, T.; Trueman, S.J. A Review of Benefits and Challenges in Growing Street Trees in Paved Urban Environments. Landsc. Urban Plan. 2015, 134, 157-166. [CrossRef]

12. Escobedo, F.J.; Kroeger, T.; Wagner, J.E. Urban Forests and Pollution Mitigation: Analyzing Ecosystem Services and Disservices. Environ. Pollut. 2011, 159, 2078-2087. [CrossRef]

13. City of Seattle. Street Tree Planting Procedures. Available online: http://www.seattle.gov/transportation/treeswithreservations. htm (accessed on 20 May 2011).

14. Castleton, H.F.; Stovin, V.; Beck, S.B.M.; Davison, J.B. Green Roofs; Building Energy Savings and the Potential for Retrofit. Energy Build. 2010, 42, 1582-1591. [CrossRef]

15. Ascione, F.; Bianco, N.; de' Rossi, F.; Turni, G.; Vanoli, G.P. Green Roofs in European Climates. Are Effective Solutions for the Energy Savings in Air-Conditioning? Appl. Energy 2013. [CrossRef]

16. Rowe, D.B. Green Roofs as a Means of Pollution Abatement. Environ. Pollut. 2011. [CrossRef]

17. Czemiel Berndtsson, J. Green Roof Performance towards Management of Runoff Water Quantity and Quality: A Review. Ecol. Eng. 2010, 36, 351-360. [CrossRef]

18. Ye, J.; Liu, C.; Zhao, Z.; Li, Y.; Yu, S. Heavy Metals in Plants and Substrate from Simulated Extensive Green Roofs. Ecol. Eng. 2013. [CrossRef]

19. Bieber, N.; Ker, J.H.; Wang, X.; Triantafyllidis, C.; van Dam, K.H.; Koppelaar, R.H.E.M.; Shah, N. Sustainable Planning of the Energy-Water-Food Nexus Using Decision Making Tools. Energy Policy 2018. [CrossRef]

20. Romero-Lankao, P.; McPhearson, T.; Davidson, D.J. The Food-Energy-Water Nexus and Urban Complexity. Nat. Clim. Chang. 2017, 7, 233-235. [CrossRef]

21. Vora, N.; Shah, A.; Bilec, M.M.; Khanna, V. Food-Energy-Water Nexus: Quantifying Embodied Energy and GHG Emissions from Irrigation through Virtual Water Transfers in Food Trade. ACS Sustain. Chem. Eng. 2017. [CrossRef]

22. Xin, X.; Ma, Y.; Liu, Y. Electric Energy Production from Food Waste: Microbial Fuel Cells versus Anaerobic Digestion. Bioresour. Technol. 2018. [CrossRef]

23. Ali, M.; Geng, Y.; Robins, D.; Cooper, D.; Roberts, W. Impact Assessment of Energy Utilization in Agriculture for India and Pakistan. Sci. Total Environ. 2019. [CrossRef]

24. Zou, Y.; Duan, X.; Xue, Z.; Mingju, E.; Sun, M.; Lu, X.; Jiang, M.; Yu, X. Water Use Conflict between Wetland and Agriculture. J. Environ. Manag. 2018. [CrossRef]

25. Weber, O.; Hogberg-Saunders, G. Water Management and Corporate Social Performance in the Food and Beverage Industry. J. Clean. Prod. 2018. [CrossRef]

26. Jin, Y.; Tang, X.; Feng, C.; Höök, M. Energy and Water Conservation Synergy in China: 2007-2012. Resour. Conserv. Recycl. 2017. [CrossRef]

27. Feng, C.; Tang, X.; Jin, Y.; Höök, M. The Role of Energy-Water Nexus in Water Conservation at Regional Levels in China. J. Clean. Prod. 2019. [CrossRef]

28. Hoff, H. Understanding the Nexus. In Proceedings of the Bonn 2011 Nexus Conference, Bonn, Germany, 16-18 November 2011. Background Paper.

29. Biggs, E.M.; Bruce, E.; Boruff, B.; Duncan, J.M.A.; Horsley, J.; Pauli, N.; McNeill, K.; Neef, A.; Van Ogtrop, F.; Curnow, J.; et al. Sustainable Development and the Water-Energy-Food Nexus: A Perspective on Livelihoods. Environ. Sci. Policy 2015. [CrossRef]

30. Mohtar, R.H.; Lawford, R. Present and Future of the Water-Energy-Food Nexus and the Role of the Community of Practice. J. Environ. Stud. Sci. 2016. [CrossRef]

31. Gao, Y.; Liu, G.; Casazza, M.; Hao, Y.; Zhang, Y.; Giannetti, B.F. Economy-Pollution Nexus Model of Cities at River Basin Scale Based on Multi-Agent Simulation: A Conceptual Framework. Ecol. Model. 2018. [CrossRef]

32. Wang, H.; Wang, X.; Song, J.; Wang, S.; Liu, X. Uncovering Regional Energy and Environmental Benefits of Urban Waste Utilization: A Physical Input-Output Analysis for a City Case. J. Clean. Prod. 2018. [CrossRef]

33. Smith, K.; Liu, S.; Liu, Y.; Guo, S. Can China Reduce Energy for Water? A Review of Energy for Urban Water Supply and Wastewater Treatment and Suggestions for Change. Renew. Sustain. Energy Rev. 2018, 91, 41-58. [CrossRef]

34. Bidoglio, G.; Vanham, D.; Bouraoui, F.; Barchiesi, S. The Water-Energy-Food-Ecosystems (WEFE) Nexus Water in the Nexus. Encycl. Ecol. 2018, 4, 459-466. [CrossRef] 
35. Birol, E.; Das, S. Estimating the Value of Improved Wastewater Treatment: The Case of River Ganga, India. J. Environ. Manag. 2010. [CrossRef]

36. UN. United Nation, World Urbanization Prospects; 2014. Available online: https://unu.edu/media-relations/releases/wwd2014un-stresses-water-energy-issues.html (accessed on 18 January 2021).

37. Barbagallo, S.; Barbera, A.C.; Cirelli, G.L.; Milani, M.; Toscano, A. Reuse of Constructed Wetland Effluents for Irrigation of Energy Crops. Water Sci. Technol. 2014. [CrossRef]

38. La Bella, S.; Tuttolomondo, T.; Leto, C.; Bonsangue, G.; Leone, R.; Virga, G.; Licata, M. Pollutant Removal Efficiency of a Pilot-Scale Horizontal Subsurface Flow in Sicily (Italy) Planted with Cyperus Alternifolius L. and Typha Latifolia L. and Reuse of Treated Wastewater for Irrigation of Arundo Donax L. for Pellet Production-Results of Two-. Desalination Water Treat. 2016. [CrossRef]

39. Ellegaard, O.; Wallin, J.A. The Bibliometric Analysis of Scholarly Production: How Great Is the Impact? Scientometrics 2015. [CrossRef] [PubMed]

40. Pötz, H.; Bleuze, P. Urban Green-Blue Grids for Sustainable and Dynamic Cities; Coop for Life: Delft, The Netherlands, 2011.

41. Schueler, T. Controlling Urban Runoff: A Practical Manual For Planning And Designing Urban BMPs (Report). Washington, D.C.: Metropolitan Washington Council of Governments. Available online: https://www.mwcog.org/documents/1987/07/01 / controlling-urban-runoff-bmp-stormwater/ (accessed on 18 July 2020).

42. Lamond, J.; Everett, G. Sustainable Blue-Green Infrastructure: A Social Practice Approach to Understanding Community Preferences and Stewardship. Landsc. Urban Plan. 2019. [CrossRef]

43. Frischenbruder, M.T.M.; Pellegrino, P. Using Greenways to Reclaim Nature in Brazilian Cities. Landsc. Urban Plan. 2006. [CrossRef]

44. Baró, F.; Calderón-Argelich, A.; Langemeyer, J.; Connolly, J.J.T. Under One Canopy? Assessing the Distributional Environmental Justice Implications of Street Tree Benefits in Barcelona. Environ. Sci. Policy 2019. [CrossRef]

45. Baek, S.; Han, M. Water-Energy-Food Nexus of Concave Green-Roof in SNU. In Proceedings of the 8th Conference of theInternational Forum on Urbanism, Incheon, Korea, 22-24 June 2015; 2015. [CrossRef]

46. Chen, B.; Han, M.Y.; Peng, K.; Zhou, S.L.; Shao, L.; Wu, X.F.; Wei, W.D.; Liu, S.Y.; Li, Z.; Li, J.S.; et al. Global Land-Water Nexus: Agricultural Land and Freshwater Use Embodied in Worldwide Supply Chains. Sci. Total Environ. 2018. [CrossRef]

47. Walsh, M.J.; Gerber Van Doren, L.; Shete, N.; Prakash, A.; Salim, U. Financial Tradeoffs of Energy and Food Uses of Algal Biomass under Stochastic Conditions. Appl. Energy 2018. [CrossRef]

48. Li, X.; Feng, K.; Siu, Y.L.; Hubacek, K. Energy-Water Nexus of Wind Power in China: The Balancing Act between CO2 Emissions and Water Consumption. Energy Policy 2012, 45, 440-448. [CrossRef]

49. Mu, J.; Khan, S. The Effect of Climate Change on the Water and Food Nexus in China. Food Secur. 2009. [CrossRef]

50. Howarth, C.; Monasterolo, I. Understanding Barriers to Decision Making in the UK Energy-Food-Water Nexus: The Added Value of Interdisciplinary Approaches. Environ. Sci. Policy 2016. [CrossRef]

51. Avellan, C.T.; Ardakanian, R.; Gremillion, P. The Role of Constructed Wetlands for Biomass Production within the Water-SoilWaste Nexus. Water Sci. Technol. 2017. [CrossRef]

52. Groenfeldt, D. Viewpoint-The next Nexus? Environmental Ethics, Water Policies, and Climate Change. Water Altern. 2010, 3,575 .

53. Dale, V.H.; Efroymson, R.A.; Kline, K.L. The Land Use-Climate Change-Energy Nexus. Landsc. Ecol. 2011. [CrossRef]

54. Mo, W.; Wang, R.; Zimmerman, J.B. Energy-Water Nexus Analysis of Enhanced Water Supply Scenarios: A Regional Comparison of Tampa Bay, Florida, and San Diego, California. Environ. Sci. Technol. 2014. [CrossRef]

55. CEC. California Energy Commission (CEC). Refining Estimates of Water-Related Energy Use in California; PIER Final Project Report (CEC-500-2006-118). 2006. Available online: http:/ /s3-us-west-2.amazonaws.com/ucldc-nuxeo-ref-media/16ff231a-63 cd-4750-8820-c0420116936f (accessed on 1 January 2021).

56. Harrison, J. Connecting the Drops-the Potential—Google Scholar. 2007. Available online: https://scholar.google.nl/scholar?hl= en\&as_sdt $=0 \% 2 \mathrm{C} 5 \& \mathrm{q}=$ Harrison $\% 2 \mathrm{C}+\mathrm{J} .+\% 282007 \% 29 .+$ Connecting + the + drops-The + potential + for + energy + conservation + in + Ontario $\backslash \mathrm{T} 1 \backslash$ textquoterights+Municipal+water+sector.+Program+in+planning $\% 2 \mathrm{C}+$ Current+issue+paper.\&btnG $=($ accessed on 21 June 2021).

57. Kenny, J.F.; Barber, N.L.; Hutson, S.S.; Linsey, K.S.; Lovelace, J.K.; Maupin, M.A. Estimated Use of Water in the United States in 2005; Circular; U.S. Geological Survey: Reston, VA, USA, 2009; Volume 1344, p. 60.

58. Sarkara, S.; Butcher, J.B.; Johnson, T.E.; Clark, C.M. Simulated Sensitivity of Urban Green Infrastructure Practices to Climate Change. Earth Interact. 2018. [CrossRef] [PubMed]

59. Schweitzer, O.; Erell, E. Evaluation of the Energy Performance and Irrigation Requirements of Extensive Green Roofs in a Water-Scarce Mediterranean Climate. Energy Build. 2014. [CrossRef]

60. Giner, M.E.; Córdova, A.; Vázquez-Gálvez, F.A.; Marruffo, J. Promoting Green Infrastructure in Mexico's Northern Border: The Border Environment Cooperation Commission's Experience and Lessons Learned. J. Environ. Manag. 2019. [CrossRef] [PubMed]

61. Nawrath, M.; Kowarik, I.; Fischer, L.K. The Influence of Green Streets on Cycling Behavior in European Cities. Landsc. Urban Plan. 2019. [CrossRef]

62. Lloyd, S.D.; Wong, T.H.F.; Porter, B. The Planning and Construction of an Urban Stormwater Management Scheme. Water Sci. Technol. 2002, 45, 1-10. [CrossRef] 
63. Whittinghill, L.J.; Rowe, D.B.; Andresen, J.A.; Cregg, B.M. Comparison of Stormwater Runoff from Sedum, Native Prairie, and Vegetable Producing Green Roofs. Urban Ecosyst. 2015. [CrossRef]

64. Edwards, G. Urban Water Management. In Water Policy in Australia: The Impact of Change and Uncertainty; Crase, L., Ed.; RFF Press: Washington, DC, USA, 2011.

65. Stout, D.T.; Walsh, T.C.; Burian, S.J. Ecosystem Services from Rainwater Harvesting in India. Urban Water J. 2017. [CrossRef]

66. Whittinghill, L.J.; Bradley Rowe, D.; Cregg, B.M. Evaluation of Vegetable Production on Extensive Green Roofs. Agroecol. Sustain. Food Syst. 2013. [CrossRef]

67. Gentry, M. Local Heat, Local Food: Integrating Vertical Hydroponic Farming with District Heating in Sweden. Energy 2019, 174, 191-197. [CrossRef]

68. Graamans, L.; Baeza, E.; van den Dobbelsteen, A.; Tsafaras, I.; Stanghellini, C. Plant Factories versus Greenhouses: Comparison of Resource Use Efficiency. Agric. Syst. 2018. [CrossRef]

69. Ezzaeri, K.; Fatnassi, H.; Bouharroud, R.; Gourdo, L.; Bazgaou, A.; Wifaya, A.; Demrati, H.; Bekkaoui, A.; Aharoune, A.; Poncet, C.; et al. The Effect of Photovoltaic Panels on the Microclimate and on the Tomato Production under Photovoltaic Canarian Greenhouses. Sol. Energy 2018. [CrossRef]

70. Hassanien, R.H.E.; Li, M. Influences of Greenhouse-Integrated Semi-Transparent Photovoltaics on Microclimate and Lettuce Growth. Int. J. Agric. Biol. Eng. 2017. [CrossRef]

71. Cerón-Palma, I.; Sanyé-Mengual, E.; Oliver-Solà, J.; Montero, J.I.; Ponce-Caballero, C.; Rieradevall, J. Towards a Green Sustainable Strategy for Social Neighbourhoods in Latin America: Case from Social Housing in Merida, Yucatan, Mexico. Habitat Int. 2013. [CrossRef]

72. Hettiarachchi, H.; Ardakanian, R. Safe Use of Wastewater in Agriculture: Good Practice Examples; Institute for Integrated Management of Material, United Nations University: Shibuya, Tokyo, 2016.

73. Avellán, T.; Gremillion, P. Constructed Wetlands for Resource Recovery in Developing Countries. Renew. Sustain. Energy Rev. 2019, 99, 42-57. [CrossRef]

74. UNWWAP. United Nations World Water Assessment Programme. The United Nations World Water Development Report 2017. Wastewater: The Untapped Resource; Paris, France, 2017. Available online: https:/ / www.unwater.org/publications/world-waterdevelopment-report-2017/ (accessed on 21 June 2021).

75. Westphal, L.M. Urban Greening and Social Benefits: A Study of Empowerment Outcomes. J. Arboric. 2003, 29, 137-147.

76. Barbosa, G.L.; Almeida Gadelha, F.D.; Kublik, N.; Proctor, A.; Reichelm, L.; Weissinger, E.; Wohlleb, G.M.; Halden, R.U. Comparison of Land, Water, and Energy Requirements of Lettuce Grown Using Hydroponic vs. Conventional Agricultural Methods. Int. J. Environ. Res. Public. Health 2015, 12, 6879. [CrossRef] [PubMed]

77. Sisco, L.; Monzer, S.; Farajalla, N.; Bashour, I.; Saoud, I.P. Roof Top Gardens as a Means to Use Recycled Waste and A/C Condensate and Reduce Temperature Variation in Buildings. Build. Environ. 2017. [CrossRef]

78. Endo, A.; Burnett, K.; Orencio, P.M.; Kumazawa, T.; Wada, C.A.; Ishii, A.; Tsurita, I.; Taniguchi, M. Methods of the Water-EnergyFood Nexus. Water Switz. 2015, 7, 5806. [CrossRef]

79. Liu, J.; Yang, H.; Cudennec, C.; Gain, A.K.; Hoff, H.; Lawford, R.; Qi, J.; de Strasser, L.; Yillia, P.T.; Zheng, C. Challenges in Operationalizing the Water-Energy-Food Nexus. Hydrol. Sci. J. 2017. [CrossRef]

80. Machell, J.; Prior, K.; Allan, R.; Andresen, J.M. The Water Energy Food Nexus-Challenges and Emerging Solutions. Environ. Sci. Water Res. Technol. 2015, 1, 15-16. [CrossRef]

81. Kaoma, H.; Shackleton, C.M. Collection of Urban Tree Products by Households in Poorer Residential Areas of Three South African Towns. Urban For. Urban Green. 2014. [CrossRef]

82. McInnes, R.J.; Everard, M. Rapid Assessment of Wetland Ecosystem Services (RAWES): An Example from Colombo, Sri Lanka. Ecosyst. Serv. 2017. [CrossRef]

83. Lawford, R.; Bogardi, J.; Marx, S.; Jain, S.; Wostl, C.P.; Knüppe, K.; Ringler, C.; Lansigan, F.; Meza, F. Basin Perspectives on the Water-Energy-Food Security Nexus. Curr. Opin. Environ. Sustain. 2013, 5, 607-616. [CrossRef]

84. Smajgl, A.; Ward, J.; Pluschke, L. The Water-Food-Energy Nexus-Realising a New Paradigm. J. Hydrol. 2016. [CrossRef]

85. Liu, Y.; Hejazi, M.; Kyle, P.; Kim, S.H.; Davies, E.; Miralles, D.G.; Teuling, A.J.; He, Y.; Niyogi, D. Global and Regional Evaluation of Energy for Water. Environ. Sci. Technol. 2016. [CrossRef]

86. NRS. I-Tree 2018 Updates Provide an Even Closer Look at Benefits of Urban Forests; United States Department of Agriculture Forest Service; Northern Research Station (NRS): Washington, DC, USA, 2018.

87. I-Tree I-Tree Eco User's Manual, V6.0Rep. USDA Forest Service; The Davey Institute: Syracuse, NY, USA; London, UK, 2016.

88. Soares, A.L.; Rego, F.C.; McPherson, E.G.; Simpson, J.R.; Peper, P.J.; Xiao, Q. Benefits and Costs of Street Trees in Lisbon, Portugal. Urban For. Urban Green. 2011. [CrossRef]

89. Simpson, E.G.M.R. Guidelines for Calculating Carbon Dioxide Reductions and through Urban Forestry Programs; General Technical Report PSW-171; U.S. Department of Agriculture, Forest Service Pacific Southwest Research Station: Albany, CA, USA, 1999.

90. Kiss, M.; Takács, Á.; Pogácsás, R.; Gulyás, Á. The Role of Ecosystem Services in Climate and Air Quality in Urban Areas: Evaluating Carbon Sequestration and Air Pollution Removal by Street and Park Trees in Szeged (Hungary). Morav. Geogr. Rep. 2015. [CrossRef]

91. Endreny, T.; Santagata, R.; Perna, A.; De Stefano, C.; Rallo, R.F.; Ulgiati, S. Implementing and Managing Urban Forests: A Much Needed Conservation Strategy to Increase Ecosystem Services and Urban Wellbeing. Ecol. Model. 2017. [CrossRef] 
92. Nair, S.; George, B.; Malano, H.M.; Arora, M.; Nawarathna, B. Water-Energy-Greenhouse Gas Nexus of Urban Water Systems: Review of Concepts, State-of-Art and Methods. Resour. Conserv. Recycl. 2014, 89, 1-10. [CrossRef]

93. El Bachawati, M.; Manneh, R.; Belarbi, R.; Dandres, T.; Nassab, C.; El Zakhem, H. Cradle-to-Gate Life Cycle Assessment of Traditional Gravel Ballasted, White Reflective, and Vegetative Roofs: A Lebanese Case Study. J. Clean. Prod. 2016. [CrossRef]

94. Bozorg Chenani, S.; Lehvävirta, S.; Häkkinen, T. Life Cycle Assessment of Layers of Green Roofs. J. Clean. Prod. 2015. [CrossRef]

95. Liu, W.; Chen, W.; Feng, Q.; Peng, C.; Kang, P. Cost-Benefit Analysis of Green Infrastructures on Community Stormwater Reduction and Utilization: A Case of Beijing, China. Environ. Manag. 2016. [CrossRef]

96. Peri, G.; Traverso, M.; Finkbeiner, M.; Rizzo, G. Embedding “Substrate” in Environmental Assessment of Green Roofs Life Cycle: Evidences from an Application to the Whole Chain in a Mediterranean Site. J. Clean. Prod. 2012. [CrossRef]

97. Spatari, S.; Yu, Z.; Montalto, F.A. Life Cycle Implications of Urban Green Infrastructure. Environ. Pollut. 2011. [CrossRef] [PubMed]

98. Vacek, P.; Struhala, K.; Matějka, L. Life-Cycle Study on Semi Intensive Green Roofs. J. Clean. Prod. 2017. [CrossRef]

99. Ottelé, M.; Perini, K.; Fraaij, A.L.A.; Haas, E.M.; Raiteri, R. Comparative Life Cycle Analysis for Green Façades and Living Wall Systems. Energy Build. 2011. [CrossRef]

100. Manso, M.; Castro-Gomes, J.; Paulo, B.; Bentes, I.; Teixeira, C.A. Life Cycle Analysis of a New Modular Greening System. Sci. Total Environ. 2018. [CrossRef]

101. Kosareo, L.; Ries, R. Comparative Environmental Life Cycle Assessment of Green Roofs. Build. Environ. 2007. [CrossRef]

102. Vineyard, D.; Ingwersen, W.W.; Hawkins, T.R.; Xue, X.; Demeke, B.; Shuster, W. Comparing Green and Grey Infrastructure Using Life Cycle Cost and Environmental Impact: A Rain Garden Case Study in Cincinnati, OH. J. Am. Water Resour. Assoc. 2015. [CrossRef]

103. O'Sullivan, A.D.; Wicke, D.; Hengen, T.J.; Sieverding, H.L.; Stone, J.J. Life Cycle Assessment Modelling of Stormwater Treatment Systems. J. Environ. Manag. 2015. [CrossRef] [PubMed]

104. Hamiche, A.M.; Stambouli, A.B.; Flazi, S. A Review of the Water-Energy Nexus. Renew. Sustain. Energy Rev. 2016, 65, 319-331. [CrossRef]

105. Jeppsson, U.; Hellström, D. Systems Analysis for Environmental Assessment of Urban Water and Wastewater Systems. Water Sci. Technol. 2002, 46, 121-129. [CrossRef]

106. Balkema, A.J.; Preisig, H.A.; Otterpohl, R.; Lambert, F.J.D. Indicators for the Sustainability Assessment of Wastewater Treatment Systems. Urban Water 2002. [CrossRef]

107. Orsini, F.; Gasperi, D.; Marchetti, L.; Piovene, C.; Draghetti, S.; Ramazzotti, S.; Bazzocchi, G.; Gianquinto, G. Exploring the Production Capacity of Rooftop Gardens (RTGs) in Urban Agriculture: The Potential Impact on Food and Nutrition Security, Biodiversity and Other Ecosystem Services in the City of Bologna. Food Secur. 2014. [CrossRef]

108. AFVAS. Agri-Food and Veterinary Authority of Singapore (AFVAS) Statistics; 2008. Available online: http://www.ava.gov.sg/AVA/ Templates / AVA-GenericContentTemplate.aspx?NRMODE=Published (accessed on 20 November 2020).

109. Singapore Statistics. 2008. Available online: www.singstat.gov.sg (accessed on 10 December 2020).

110. Barthel, S.; Isendahl, C. Urban Gardens, Agriculture, And Water Management: Sources of Resilience for Long-Term Food Security in Cities. Ecol. Econ. 2013. [CrossRef]

111. McClintock, N. Why Farm the City? Theorizing Urban Agriculture through a Lens of Metabolic Rift. Camb. J. Reg. Econ. Soc. 2010. [CrossRef]

112. Barthel, S.; Folke, C.; Colding, J. Social-Ecological Memory in Urban Gardens-Retaining the Capacity for Management of Ecosystem Services. Glob. Environ. Chang. 2010. [CrossRef]

113. Breuste, J.H.; Artmann, M. Allotment Gardens Contribute to Urban Ecosystem Service: Case Study Salzburg, Austria. J. Urban Plan. Dev. 2015. [CrossRef]

114. Lee, G.G.; Lee, H.W.; Lee, J.H. Greenhouse Gas Emission Reduction Effect in the Transportation Sector by Urban Agriculture in Seoul, Korea. Landsc. Urban Plan. 2015. [CrossRef]

115. City of Seattle. City of Seattle Launches "2010: The Year of Urban Agriculture" Campaign. City Council News Release; 3 February 2010; Seattle. Available online: http:/ /www.seattle.gov/council/newsdetail.asp?ID=10500\&Dept=28 (accessed on 20 May 2011).

116. Larondelle, N.; Strohbach, M.W. A Murmur in the Trees to Note: Urban Legacy Effects on Fruit Trees in Berlin, Germany. Urban For. Urban Green. 2016. [CrossRef]

117. von Hoffen, L.P.; Säumel, I. Orchards for Edible Cities: Cadmium and Lead Content in Nuts, Berries, Pome and Stone Fruits Harvested within the Inner City Neighbourhoods in Berlin, Germany. Ecotoxicol. Environ. Saf. 2014. [CrossRef]

118. Chen, C.J.; Shih, H.A.; Yang, S.Y. The Role of Intellectual Capital in Knowledge Transfer. IEEE Trans. Eng. Manag. 2009. [CrossRef]

119. Basher, S.A.; Raboy, D.; Kaitibie, S.; Hossain, I. Understanding Challenges to Food Security in Dry Arab Micro-States: Evidence from Qatari Micro-Data. J. Agric. Food Ind. Organ. 2013. [CrossRef]

120. Huang, B.; Shi, X.; Yu, D.; Öborn, I.; Blombäck, K.; Pagella, T.F.; Wang, H.; Sun, W.; Sinclair, F.L. Environmental Assessment of Small-Scale Vegetable Farming Systems in Peri-Urban Areas of the Yangtze River Delta Region, China. Agric. Ecosyst. Environ. 2006. [CrossRef]

121. Vazquez Morales, W.; Jazcilevich, A.; Reynoso, A.G.; Caetano, E.; Gomez, G.; Bornstein, R.D. Influence of Green Roofs on Early Morning Mixing Layer Depths in Mexico City. J. Sol. Energy Eng. Trans. ASME 2016. [CrossRef] 
122. Russo, A.; Escobedo, F.J.; Cirella, G.T.; Zerbe, S. Edible Green Infrastructure: An Approach and Review of Provisioning Ecosystem Services and Disservices in Urban Environments. Agric. Ecosyst. Environ. 2017, 242, 53-66. [CrossRef]

123. Ng, K.T.; Herrero, P.; Hatt, B.; Farrelly, M.; McCarthy, D. Biofilters for Urban Agriculture: Metal Uptake of Vegetables Irrigated with Stormwater. Ecol. Eng. 2018. [CrossRef]

124. Miller-Robbie, L.; Ramaswami, A.; Amerasinghe, P. Wastewater Treatment and Reuse in Urban Agriculture: Exploring the Food, Energy, Water, and Health Nexus in Hyderabad, India. Environ. Res. Lett. 2017. [CrossRef]

125. Wielemaker, R.C.; Weijma, J.; Zeeman, G. Harvest to Harvest: Recovering Nutrients with New Sanitation Systems for Reuse in Urban Agriculture. Resour. Conserv. Recycl. 2018. [CrossRef]

126. Ziegler, R. The Vertical Aeroponic Growing System; Synergyii International Inc., 2005. Available online: https://www.academia. edu/1588076/The_vertical_aeroponic_growing_system (accessed on 5 December 2020).

127. NEAS. Information on Annual Rainfall. Available online: http:app2.nea.gov.sg/emag/our_climate.html (accessed on 24 July 2009).

128. HDB. Housing and Development Board. Annual Report (2007/2008); Housing and Development Board: Singapore, 2008.

129. Turcios, A.E.; Papenbrock, J. Sustainable Treatment of Aquaculture Effluents-What Can We Learn from the Past for the Future? Sustain. Switz. 2014, 6, 836-856. [CrossRef]

130. Liu, D.; Wu, X.; Chang, J.; Gu, B.; Min, Y.; Ge, Y.; Shi, Y.; Xue, H.; Peng, C.; Wu, J. Constructed Wetlands as Biofuel Production Systems. Nat. Clim. Chang. 2012. [CrossRef]

131. Schwärzel, K.; Ardakanian, R.; Avellán, T.; Zhang, L. Nexus Approach: Resource Management for Soil Productivity; CRC Press: Boca Raton, FL, USA, 2016; ISBN 978-1-4987-3890-3.

132. Zheng, X.; Wei, C.; Qin, P.; Guo, J.; Yu, Y.; Song, F.; Chen, Z. Characteristics of Residential Energy Consumption in China: Findings from a Household Survey. Energy Policy 2014. [CrossRef]

133. Shao, L.; Wu, Z.; Zeng, L.; Chen, Z.M.; Zhou, Y.; Chen, G.Q. Embodied Energy Assessment for Ecological Wastewater Treatment by a Constructed Wetland. Ecol. Model. 2013. [CrossRef]

134. Livesley, S.J.; McPherson, E.G.; Calfapietra, C. The Urban Forest and Ecosystem Services: Impacts on Urban Water, Heat, and Pollution Cycles at the Tree, Street, and City Scale. J. Environ. Qual. 2016. [CrossRef]

135. Amani-Beni, M.; Zhang, B.; di Xie, G.; Xu, J. Impact of Urban Park's Tree, Grass and Waterbody on Microclimate in Hot Summer Days: A Case Study of Olympic Park in Beijing, China. Urban For. Urban Green. 2018. [CrossRef]

136. dos Santos, S.M.; Silva, J.F.F.; dos Santos, G.C.; de Macedo, P.M.T.; Gavazza, S. Integrating Conventional and Green Roofs for Mitigating Thermal Discomfort and Water Scarcity in Urban Areas. J. Clean. Prod. 2019. [CrossRef]

137. McGovern, M.; Pasher, J. Canadian Urban Tree Canopy Cover and Carbon Sequestration Status and Change 1990-2012. Urban For. Urban Green. 2016. [CrossRef]

138. Park, J.H.; Baek, S.G.; Kwon, M.Y.; Je, S.M.; Woo, S.Y. Volumetric Equation Development and Carbon Storage Estimation of Urban Forest in Daejeon, Korea. For. Sci. Technol. 2018. [CrossRef]

139. Thiagarajan, M.; Newman, G.; Van Zandt, S. The Projected Impact of a Neighborhood-Scaled Green-Infrastructure Retrofit. Sustain. Switz. 2018, 10, 3665. [CrossRef] [PubMed]

140. Goldstein, B.; Hauschild, M.; Fernández, J.; Birkved, M. Testing the Environmental Performance of Urban Agriculture as a Food Supply in Northern Climates. J. Clean. Prod. 2016. [CrossRef]

141. Mohareb, E.; Heller, M.; Novak, P.; Goldstein, B.; Fonoll, X.; Raskin, L. Considerations for Reducing Food System Energy Demand While Scaling up Urban Agriculture. Environ. Res. Lett. 2017. [CrossRef]

142. Sun, R.; Chen, A.; Chen, L.; Lü, Y. Cooling Effects of Wetlands in an Urban Region: The Case of Beijing. Ecol. Indic. 2012. [CrossRef]

143. Li, C.; Yu, C.W. Mitigation of Urban Heat Development by Cool Island Effect of Green Space and Water Body. In Proceedings of the 8th International Symposium on Heating, Ventilation and Air Conditioning; Li, A., Zhu, Y., Li, Y., Eds.; Springer: Berlin/Heidelberg, Germany, 2014; pp. 551-561.

144. Gunawardena, K.R.; Wells, M.J.; Kershaw, T. Utilising Green and Bluespace to Mitigate Urban Heat Island Intensity. Sci. Total Environ. 2017. [CrossRef]

145. Zhao, L.; Lee, X.; Smith, R.B.; Oleson, K. Strong Contributions of Local Background Climate to Urban Heat Islands. Nature 2014. [CrossRef]

146. Xue, Z.; Hou, G.; Zhang, Z.; Lyu, X.; Jiang, M.; Zou, Y.; Shen, X.; Wang, J.; Liu, X. Quantifying the Cooling-Effects of Urban and Peri-Urban Wetlands Using Remote Sensing Data: Case Study of Cities of Northeast China. Landsc. Urban Plan. 2019. [CrossRef]

147. Egwu, G.N.; Agbenin, J.O. Field Assessment of Cadmium, Lead and Zinc Contamination of Soils and Leaf Vegetables under Urban and Peri-Urban Agriculture in Northern Nigeria. Arch. Agron. Soil Sci. 2013. [CrossRef]

148. Lõhmus, M.; Balbus, J. Making Green Infrastructure Healthier Infrastructure. Infect. Ecol. Epidemiol. 2015. [CrossRef] [PubMed]

149. Kranert, M.; Gottschall, R.; Bruns, C.; Hafner, G. Energy or Compost from Green Waste?-A CO ${ }_{2}$-Based Assessment. Waste Manag. 2010. [CrossRef]

150. Liu, L.Q.; Liu, C.X.; Sun, Z.Y. A Survey of China's Low-Carbon Application Practice-Opportunity Goes with Challenge. Renew. Sustain. Energy Rev. 2011, 15, 2895-2903. [CrossRef]

151. Koh, L.P.; Tan, H.T.W.; Sodhi, N.S. Biofuels: Waste Not Want Not. Science 2008. [CrossRef] [PubMed] 
152. Shi, Y.; Ge, Y.; Chang, J.; Shao, H.; Tang, Y. Garden Waste Biomass for Renewable and Sustainable Energy Production in China: Potential, Challenges and Development. Renew. Sustain. Energy Rev. 2013, 22, 432-437. [CrossRef]

153. Syme, G.J.; Shao, Q.; Po, M.; Campbell, E. Predicting and Understanding Home Garden Water Use. Landsc. Urban Plan. 2004. [CrossRef]

154. Domene, E.; Saurí, D. Urbanisation and Water Consumption: Influencing Factors in the Metropolitan Region of Barcelona. Urban Stud. 2006. [CrossRef]

155. Livesley, S.J.; Dougherty, B.J.; Smith, A.J.; Navaud, D.; Wylie, L.J.; Arndt, S.K. Soil-Atmosphere Exchange of Carbon Dioxide, Methane and Nitrous Oxide in Urban Garden Systems: Impact of Irrigation, Fertiliser and Mulch. Urban Ecosyst. 2010. [CrossRef]

156. Morris, J.; Bagby, J. Measuring Environmental Value for Natural Lawn and Garden Care Practices. Int. J. Life Cycle Assess. 2008. [CrossRef]

157. Ouldboukhitine, S.E.; Belarbi, R.; Jaffal, I.; Trabelsi, A. Assessment of Green Roof Thermal Behavior: A Coupled Heat and Mass Transfer Model. Build. Environ. 2011. [CrossRef]

158. Niu, H.; Clark, C.; Zhou, J.; Adriaens, P. Scaling of Economic Benefits from Green Roof Implementation in Washington, DC. Environ. Sci. Technol. 2010. [CrossRef]

159. Niachou, A.; Papakonstantinou, K.; Santamouris, M.; Tsangrassoulis, A.; Mihalakakou, G. Analysis of the Green Roof Thermal Properties and Investigation of Its Energy Performance. Energy Build. 2001. [CrossRef]

160. Berardi, U. The Outdoor Microclimate Benefits and Energy Saving Resulting from Green Roofs Retrofits. Energy Build. 2016. [CrossRef]

161. Shafique, M.; Kim, R.; Rafiq, M. Green Roof Benefits, Opportunities and Challenges-A Review. Renew. Sustain. Energy Rev. 2018, 90, 757-773. [CrossRef]

162. Kim, R. Low Impact Development and Green Infrastructure in South Korea: Trends and Future Directions. Ecol. Resilient Infrastruct. 2016. [CrossRef]

163. Award Winner. The 2016 Green Roof and Wall Awards of Excellence, Green Roofs for Healthy Cities. 2016. Available online: http:/ / www.greenroofs.org/index.php/resources/awardsof-excellence/2016-award-winners (accessed on 24 January 2021).

164. Silva, C.M.; Flores-Colen, I.; Antunes, M. Step-by-Step Approach to Ranking Green Roof Retrofit Potential in Urban Areas: A Case Study of Lisbon, Portugal. Urban For. Urban Green. 2017. [CrossRef]

165. Andersson, E.; Barthel, S.; Ahrné, K. Measuring Social-Ecological Dynamics behind the Generation of Ecosystem Services. Ecol. Appl. 2007. [CrossRef]

166. Daily, G.C.; Matson, P.A. Ecosystem Services: From Theory to Implementation. Proc. Natl. Acad. Sci. USA 2008, 105, 9455-9456. [CrossRef]

167. Rodríguez, J.P.; Beard, T.D.; Bennett, E.M.; Cumming, G.S.; Cork, S.J.; Agard, J.; Dobson, A.P.; Peterson, G.D. Trade-Offs across Space, Time, and Ecosystem Services. Ecol. Soc. 2006. [CrossRef]

168. Cox, S.; Searle, B. The State of Ecosystem-Google Scholar. 2009. Available online: https://scholar.google.nl/scholar?hl=en\& as_sdt $=0 \% 2 \mathrm{C} 5 \& q=\mathrm{Cox} \% 2 \mathrm{C}+\mathrm{S} . \% 2 \mathrm{C}+$ and + Searle $\% 2 \mathrm{C}+\mathrm{B} .+\% 282009 \% 29 .+$ The + state + of + ecosystem + services.+The+Bridgespan + Group.\&btnG $=$ (accessed on 21 June 2021).

169. Haines-Young, R.; Potschin, M. Common International Classification of Ecosystem Services (CICES): 2011 Update European Environment Agency. 2011. Available online: https://cices.eu/content/uploads/sites/8/2009/11/CICES_Update_Nov2011.pdf (accessed on 18 July 2020).

170. United Nations, Department of Economic and Social Affairs, Population Division. World Urbanization Prospects. 2008. Available online: http:/ / esa.un.org/unup (accessed on 2 July 2009).

171. Puri, V.; Caplow, T. How to grow food in the 100\% renewable city: Building-integrated agriculture. In 100 Per Cent Renewable: Energy Autonomy in Action, 1st ed.; Peter, D., Ed.; Earth Scane: London, UK, 2009; ISBN 978-1-84977-434-5.

172. Benis, K.; Turan, I.; Reinhart, C.; Ferrão, P. Putting Rooftops to Use-A Cost-Benefit Analysis of Food Production vs. Energy Generation under Mediterranean Climates. Cities 2018. [CrossRef]

173. Specht, K.; Siebert, R.; Hartmann, I.; Freisinger, U.B.; Sawicka, M.; Werner, A.; Thomaier, S.; Henckel, D.; Walk, H.; Dierich, A Urban Agriculture of the Future: An Overview of Sustainability Aspects of Food Production in and on Buildings. Agric. Hum. Values 2014. [CrossRef]

174. Benis, K.; Reinhart, C.; Ferrão, P. Development of a Simulation-Based Decision Support Workflow for the Implementation of Building-Integrated Agriculture (BIA) in Urban Contexts. J. Clean. Prod. 2017. [CrossRef]

175. Benis, K.; Ferrão, P. Potential Mitigation of the Environmental Impacts of Food Systems through Urban and Peri-Urban Agriculture (UPA)—A Life Cycle Assessment Approach. J. Clean. Prod. 2017. [CrossRef]

176. Marta-Pedroso, C.; Domingos, T.; Freitas, H.; de Groot, R.S. Cost-Benefit Analysis of the Zonal Program of Castro Verde (Portugal): Highlighting the Trade-off between Biodiversity and Soil Conservation. Soil Tillage Res. 2007. [CrossRef]

177. Kremer, P.; Hamstead, Z.A.; McPhearson, T. A Social-Ecological Assessment of Vacant Lots in New York City. Landsc. Urban Plan. 2013. [CrossRef]

178. McPhearson, T.; Kremer, P.; Hamstead, Z.A. Mapping Ecosystem Services in New York City: Applying a Social-Ecological Approach in Urban Vacant Land. Ecosyst. Serv. 2013. [CrossRef]

179. Clinton, N.; Stuhlmacher, M.; Miles, A.; Uludere Aragon, N.; Wagner, M.; Georgescu, M.; Herwig, C.; Gong, P. A Global Geospatial Ecosystem Services Estimate of Urban Agriculture. Earths Future 2018. [CrossRef] 
180. Metson, G.S.; Bennett, E.M. Phosphorus Cycling in Montreal's Food and Urban Agriculture Systems. PLoS ONE 2015, 10, e0120726. [CrossRef]

181. Lewis, O.; Home, R.; Kizos, T. Digging for the Roots of Urban Gardening Behaviours. Urban For. Urban Green. 2018. [CrossRef]

182. Sanchez, C.; Childers, D.L.; Turnbull, L.; Upham, R.F.; Weller, N. Aridland Constructed Treatment Wetlands II: Plant Mediation of Surface Hydrology Enhances Nitrogen Removal. Ecol. Eng. 2016, 97, 658-665. [CrossRef]

183. Bois, P.; Beisel, J.-N.; Heitz, C.; Katinka, L.; Laurent, J.; Pierrette, M.; Walaszek, M.; Wanko, A. Integrated Blue and Green Corridor Restoration in Strasbourg: Green Toads, Citizens, and Long-Term Issues. In Ecological Wisdom Inspired Restoration Engineering; Springer: Berlin/Heidelberg, Germany, 2019; pp. 151-169.

184. McDougall, R.; Kristiansen, P.; Rader, R. Small-Scale Urban Agriculture Results in High Yields but Requires Judicious Management of Inputs to Achieve Sustainability. Proc. Natl. Acad. Sci. USA 2019. [CrossRef] [PubMed] 